\title{
Some Aspects of the Ecology of a Potentially Invasive Species in Martinique: The Case of Dichrostachys cinerea
}

\author{
Yelji Abati ${ }^{1}$, Philippe Joseph ${ }^{1}$, Kévine Baillard ${ }^{1}$, Jean-Philippe \\ Claude ${ }^{1}$, Yanis Jean-Francois ${ }^{1}$, Séverine Ely-Marius ${ }^{1}$, Stéphane \\ Sophie ${ }^{1}$, Jean-Emile Simphor ${ }^{1}$, Péguy Major ${ }^{1}$, Jean-Valérie Marc ${ }^{1}$
}

${ }^{1}$ Laboratoire BIORECA (Biodiversités Risques Écologiques en territoires insulaires Caraïbes), UMR Espace DEV, Université des Antilles, Martinique

\begin{abstract}
Biological invasions are the second most significant cause of biodiversity loss. They lead to the introduction of exogenous plant species which today threaten autochthonous and/or endemic species. Indeed, many plant species have disappeared. Other highly endangered species are currently in danger of extinction. Human activities, the overexploitation of resources, climate change but also biological invasions have advanced these extinctions. These phenomena have led to the progressive deterioration of the environments and a decrease in the diversity of the landscapes (a considerable depletion of the plant ecosystem) thus contributing to a loss of biodiversity._Natural (cyclones, etc.) or anthropogenic (pollution, etc.) perturbations create openings in the ground cover allowing more competitive species to install themselves. Introduced plant species install themselves in the open areas caused by these perturbations. They overcome a succession of barriers (physical, geographic, environmental) before they can become invasive. When conditions are favourable to their installation, they develop there to the detriment of the native populations. Insular environments (islands) are more sensitive to the phenomena of biological invasions. In Martinique, forests have gradually degraded and are losing their ecosystem resilience. This favours the installation and development of invasive species. Dichrostachys cinerea is an introduced species which is native to Africa and which has become naturalised on the island of Martinique. It colonises extensively perturbed areas, fallow land, abandoned farm plots located in the south of the island. A floristic analysis of the forests of the communes of southern Martinique (Sainte Anne, Marin, Vauclin) was carried out in order to establish the ecological profile of this shrub.
\end{abstract}

Keywords: Dichrostachys cinerea, Lesser Antilles, Martinique, Biodiversity, Potentially Invasive Plant, Anthropisation

\begin{abstract}
Introduction
Invasive alien species are the second leading cause of biodiversity loss (Vitousek et al., 1997). Man has long contributed to the influx of plant species outside their natural distribution range when travelling to the New World or conquering territories. Some of these introduced species have adapted to their new environment. During their development, they have gradually expanded their regenerations to the detriment of the autochthonous and/or indigenous plant species of the given territory. In addition to their rapid growth, invasive alien plant species possess great ecological plasticity (Jakobs et al., 2004; Richards et al., 2006; Terral and Ater, 2016). This gives them the ability to expand their ecological niches in different environmental conditions.
\end{abstract}

In addition, these taxa tend to alter the characteristics of the environment (the chemical composition of the soil, etc.) or the specific interactions with indigenous plant communities, thereby reducing local biodiversity.

\begin{abstract}
Insular ecosystems are very sensitive to these invasion phenomena. Their geographic isolation and limited surface area are two features which favour the installation of invasive alien species (Vitousek and Walker, 1989).

Martinique contains approximately 3200 plant species (Howard, 1988; Fournet, 2002) of which 1536 are indigenous or autochthonous species (48\%), 236 are naturalised (about 7\%), 846 are cultivated species $(26 \%), 180$ are in the process of naturalising (about 6\%) and the remaining 405 species are likely to have disappeared or were not found.
\end{abstract}

The first studies of invasive alien species in Martinique were led by Professor Philippe Joseph (Joseph, 1999). They enabled him to establish the 
ecological profile and the potential for invasion of these species.

Following this research work, he identified ten species with the potential for invasion in Martinique (Bambusa vulgaris Schrad. Ex Wendl., Castilla elastica Sessé, Dichrostachys cinerea (L.) Wight \& Arn., Eichhornia crassipes (Mart.) Solms, Funtumia elastica (P. Preuss) Stapf, Mimosa malacocentra (C. Mart.) Benth., Oeceoclades maculata (Lindl.) Lindl, Pistia stratiotes, Spathodea campanulata (P. Beauv.), Thunbergia grandiflora (Roxb. Ex Rottl.) Roxb, Triphasia trifolia (Burm.f.) P. Wilson) (Joseph, 2012; Fournet, 2002).

These potentially invasive species develop in perturbed regions of xeric, mesophilous or

\section{$1.1 \quad$ Study site}

Located in the centre of the island arc of the Lesser Antilles, the island of Martinique has a total surface area of $1,128 \mathrm{~km}^{2}$. The humid tropical climate is marked by two seasons: a dry season or carême (Lent) that corresponds to the drought period from

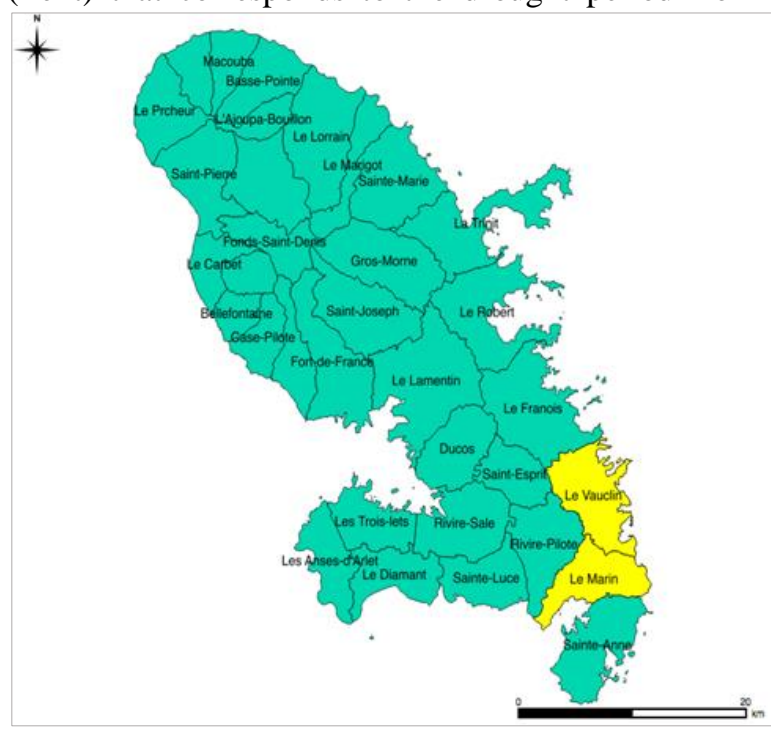

Figure 0.1 : Geographical representation of the study areas (shown in yellow on the map) hygrophilous environments (especially Funtumia elastica) and expand their populations to form dense monospecific stands.

Dichrostachys cinerea (L.) Wight \& Arn is an invasive bush or shrub (Fournet, 2002), introduced in the $19^{\text {th }}$ century in the French West Indies. The species proliferates in deciduous xeric forests, fields, roadsides, agricultural areas and other perturbed areas. It causes significant agricultural losses and managing it requires resources which are extremely costly.

This paper aims to outline the main life history traits of Dichrostachys cinerea in the xeric formations of Martinique and to establish its ecological profile.

February to April, and a wet (or rainy) season that runs from May to November. Its highest peak, Mount Pelée, rises to $1,397 \mathrm{~m}$. The numerous reliefs (mountainous massifs) create climatic variations which initiate a bioclimatic staging. This staging gives rise to several types of vegetation ranging from dry to hyper-humid.

Annual rainfall varies from coastline to mountains from $500 \mathrm{~mm}$ (Sainte-Anne) to more than $6,000 \mathrm{~mm}$ (on Mount Pelée and the Carbet Miountains) (Meteo France).

A floristic survey was carried out by the BIORECA team in July 2015 in the commune of Vauclin in the locality of Morne Carrière, and then in January 2017 in the commune of Marin in Duprey. Other inventories were carried out in July 2017 in the two communes mentioned above in the localities of Morne Jalouse (Vauclin) and Pointe Borgnèse (Marin). The communes surveyed (Vauclin and Marin) are indicated in yellow on the map of Martinique.

The minimum and maximum annual temperatures of the study areas were $23^{\circ} \mathrm{C}$ and $28^{\circ} \mathrm{C}$ respectively with annual precipitation not exceeding $1,500 \mathrm{~mm}$, which corresponds to a dry bioclimate.

Table 2.1: Ecosystemic potentialities and bioclimates according to rainfall (Joseph, 2011)

\begin{tabular}{|c|c|c|}
\hline Average annual rainfall & Bioclimates & Ecosystemic potentialities \\
\hline $1500 \mathrm{~mm}$ & Dry & $\begin{array}{l}\text { Seasonal evergreen forest of lower horizon and xeric facies (dry } \\
\text { forest) }\end{array}$ \\
\hline $1500-2500 \mathrm{~mm}$ & Moderately humid & Tropical seasonal evergreen forest (mesophilous forest) \\
\hline $2500-4000 \mathrm{~mm}$ & Humid & Tropical sub-montane ombrophilous forest (hygrophilous forest) \\
\hline More than $4000 \mathrm{~mm}$ & Hyperhumid & Tropical montane rainforest (mountain hygrophilous forest) \\
\hline
\end{tabular}




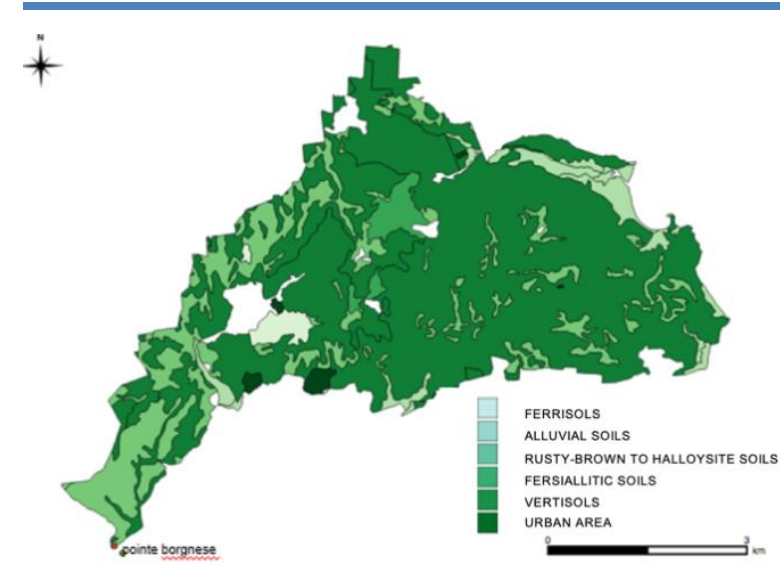

Figure 0.2: Pedological map of the commune of Marin

Several areas showing plant formations at different dynamic and ecological stages were inventoried by the BIORECA team. Among those inventoried, we chose to present fourteen which were at more or less advanced stages of development, marked by the greater or lesser presence of the species Dichrostachys cinerea. With the help of data from the National Geographic Institute (IGN in the French acronym), we were able to extract maps revealing the Dichrostachys cinerea or Acacia Saint-Domingue or marabout in some parts of the world, especially Africa - is a shrub or bush of the Mimosaceae family, Saman family, of the Inga. It was introduced in the Lesser Antilles in the $19^{\text {th }}$ century after having colonised certain islands of the Greater Antilles (Cuba). It is native to southern and tropical Africa.

The fruits of this mimosaceae were introduced from the Greater Antilles when cattle were imported for the production of meat.

Today, the species has a large geographical distribution worldwide. Large populations of the species are found in the tropics.

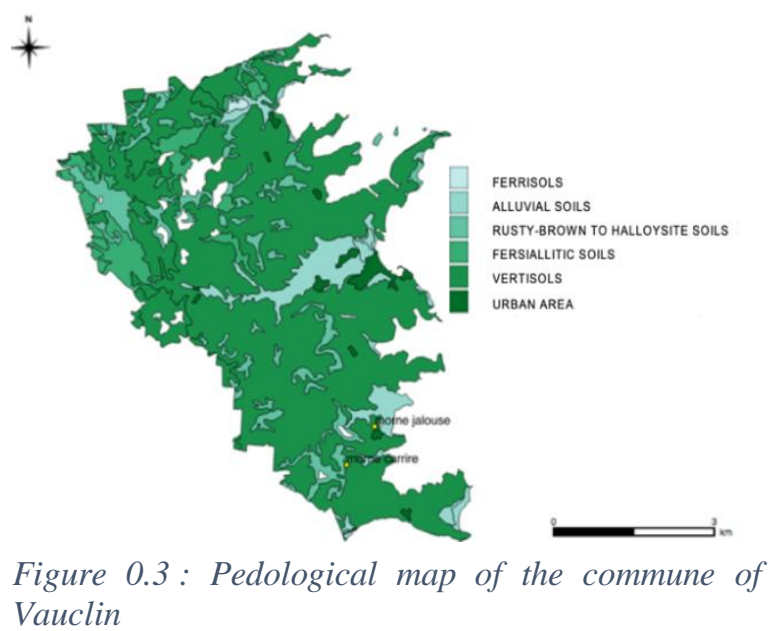

different soil types of Martinique. These revealed the presence of two types of soils in the study area: vertisols and brown soils containing halloysites. A characteristic of these soils is that they develop in dry areas (with rainfall of less than $1500 \mathrm{~mm}$ ).

\subsection{Some descriptive aspects of the Dichrostachys cinerea (Mimosaceae)}

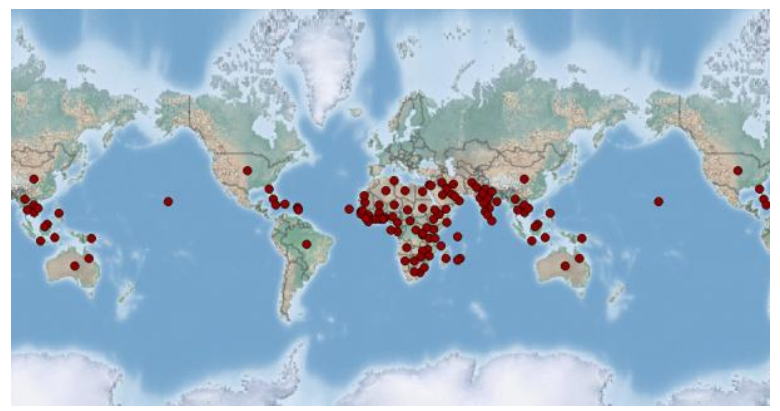

Figure 0.4 : Distribution of Dichrostachys cinerea (https://www.cabi.org/isc/datasheet/18119)

It is an aggressive invasive plant with the ability to grow in sunny open areas as well as in severely degraded areas, especially in abandoned agricultural plots, fallow land in dry bioclimate. It is found mostly in poor soils which have been degraded by agriculture along the coast of Martinique. In Martinique, it is found in low-lying regions (0 - 200 $\mathrm{m})$ although it is also found in tropical forests at up to $2000 \mathrm{~m}$ altitude. It is spread mainly by seeds which can be easily dispersed by animals, although it is propagated by suckers (GISD) and by barochory (large bank of seeds viable in the soil). 

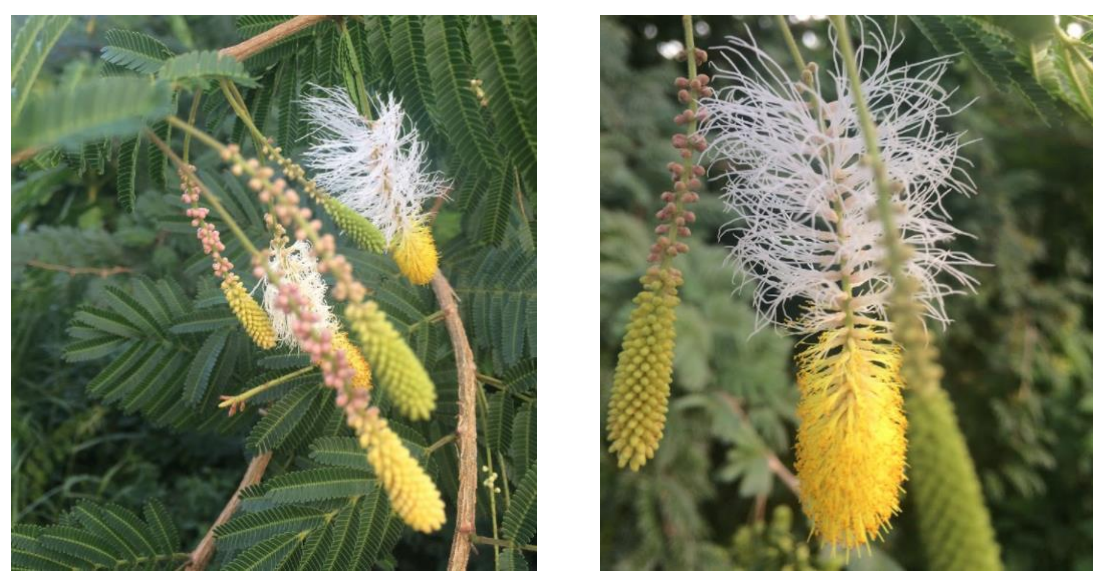

Figure 0.5 : Inflorescences of Dichrostachys cinerea (Photo ABATI Y., 2017)

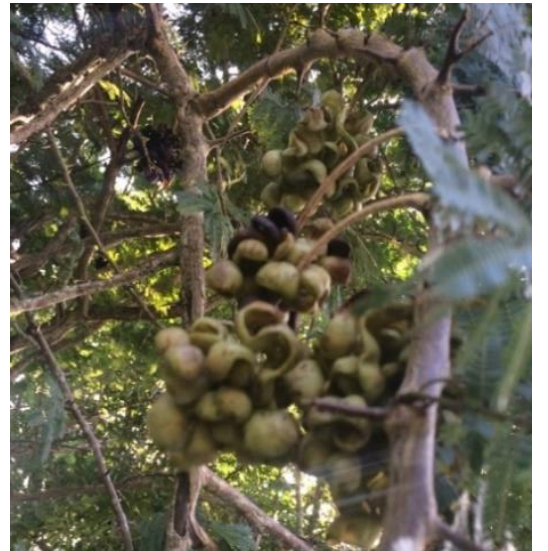

Figure 0.6 : Infructescences of

Dichrostachys cinerea (Photo ABATI Y., 2017)

This species tends to form dense and impenetrable monospecific thickets in degraded xeric formations. The bark of the young twigs is green and quite densely pubescent, while that of adult twigs is brown with many whitish lenticels. Its bipinnate leaves are composed of 5 to 10 pairs of pinnae with leaflets of 10 to 30 pairs of pinnae. The fragrant flowers are characterised by a bicolour inflorescence in racemes: pink or white in the upper part and yellow in the lower part. The upper flowers are sterile with protruding staminodes. The staminodes are pink when they open and then change gradually to white in maturity. The lower flowers are hermaphroditic

\section{Method}

The method proposed by Professor Philippe Joseph is based on floristic inventories. During these inventories, we demarcate a study area called a transect which is divided into quadrats. The surface

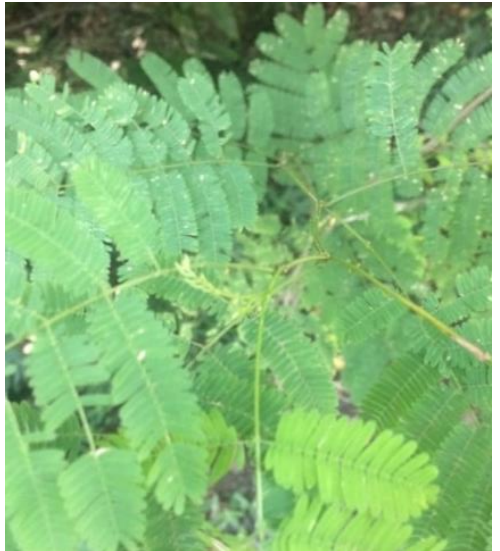

Figure 0.7 : Leaves of Dichrostachys cinerea (Photo ABATI Y., 2017)

with a pistil and 10 yellow stamens. The fruits are dark brown pods and twisted in the form of clusters which contain pale brown biconvex seeds. The pods give off a strong aroma which attracts animals and this facilitates the dispersal of the seeds.

This species has many uses. In agroforestry, it is used to improve and rehabilitate soils, to stabilise sand dunes and to fight against erosion. It also has medicinal uses; indeed the bark, roots and leaves are used to treat headaches, toothaches and stings and also to treat snake bites, syphilis and gonorrhoea.

area of the transect varies between 500 and $1000 \mathrm{~m}^{2}$ depending on the plant formations. We look at the descriptors: scientific name, total height, first branch height, trunk diameter (measured at $1.33 \mathrm{~m}$ from the ground according to international standards: diametric class). 


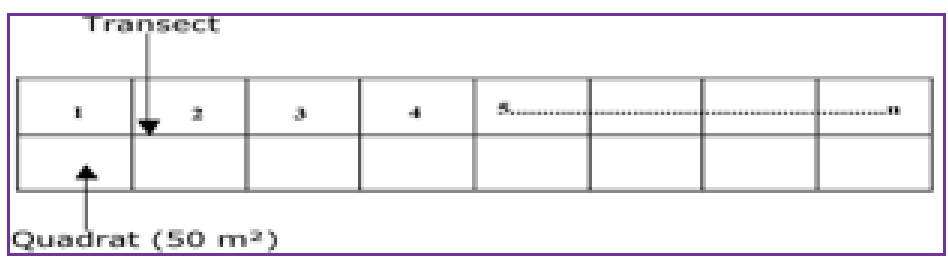

Figure 0.8 : Representation of a transect composed of quadrats

The ecological and structural parameters taken into account in this study are the following:

- The absolute frequency $f_{a}$, that is to say the number of times a given species was observed in the quadrats or in the stations. It characterises the distribution of the species within each quadrat;

- The relative frequency $f_{r}$, ratio of the absolute frequency to the total number of quadrats in a transect or of stations;

- The density, corresponding to the number of individuals in the survey area;

- The index of distribution $\mathrm{I}_{\mathrm{d}}=\mathrm{f}_{\mathrm{r}} * \mathrm{~d}$ (density, defined as the ratio between the number of individuals of the species considered and the basal area $S_{t}$ ). It allows us to ascertain the modalities of occupation of the space by the species population in the station;

- The index of dominance (ID) enables us to determine species dominance with regards to each other, and is obtained by the following relation: $\mathrm{ID}=\mathrm{Id} * \mathrm{~S}_{\mathrm{t}}$ (basal area);

- The CFA: the comparison between the stations was done by means of a confirmatory factor analysis (CFA) using the software XLSTAT;

- The AHC: the comparison of the hierarchical links between individuals and groups of individuals was carried out using ascending hierarchical classification.

\section{Results}

The results are presented in the form of tables which show the main ecological and structural parameters used to characterise each of the stations with regards to each other.

\subsection{Low dominance} Station C1

Table 0.1 : The main ecological and structural parameters (Station C1)

\begin{tabular}{|c|c|c|c|c|c|c|c|c|}
\hline Rank & Species C1 & fa & fr & $\begin{array}{l}\text { Number of individuals per species } \\
\text { excluding regenerations and dead trees }\end{array}$ & $\begin{array}{l}\text { Density } \\
\text { (ind } / \mathbf{m}^{2} \text { ) }\end{array}$ & Id & $\begin{array}{l}\text { Total basal area } \\
\text { per species }\end{array}$ & ID \\
\hline 1 & Pisonia fragrans & 9 & $90 \%$ & 134 & 0.134 & 0.1206 & 0.4604 & 5.5529E-02 \\
\hline 2 & $\begin{array}{l}\text { Haematoxylon } \\
\text { campechianum }\end{array}$ & 6 & $60 \%$ & 74 & 0.074 & 0.0444 & 0.5149 & 2.2863E-02 \\
\hline 3 & Citharexylum spinosum & 9 & $90 \%$ & 38 & 0.038 & 0.0342 & 0.2420 & 8.2764E-03 \\
\hline 18 & Dichrostachys cinerea & 2 & $20 \%$ & 8 & 0.008 & 0.0016 & 0.0187 & $5.0265 \mathrm{E}-05$ \\
\hline
\end{tabular}

Absolute frequency $(\mathrm{fa})=$ presence of the species in the different quadrats; Relative frequency $($ fr $)=A b s o l u t e$ frequency / by the number of quadrats; Density = number of individuals / survey area; Index of distribution (Id) = Relative frequency * Density; Index of dominance $(I D)=$ Index of distribution $*$ basal area

Station C1 describes a seasonal tropical evergreen formation of lower horizon and xeric facies at the secondary to young forest stage dominated by the population of Pisonia fragrans. The latter has a population balance between regenerations and mature individuals. The predominant species of the station are - in order of ecological significance - Pisonia fragrans and Haematoxylon campechianum.
While Pisonia fragrans displays a relatively high relative frequency and density, Haematoxylon campechianum presents a relatively low number of individuals weighted by a high basal area, demonstrated by individuals with large section measurements (reaching up to $50 \mathrm{~cm}$ ). Dichrostachys cinerea, an invasive species, is present in the station but with low distribution (20\%) (Table 4.1). 


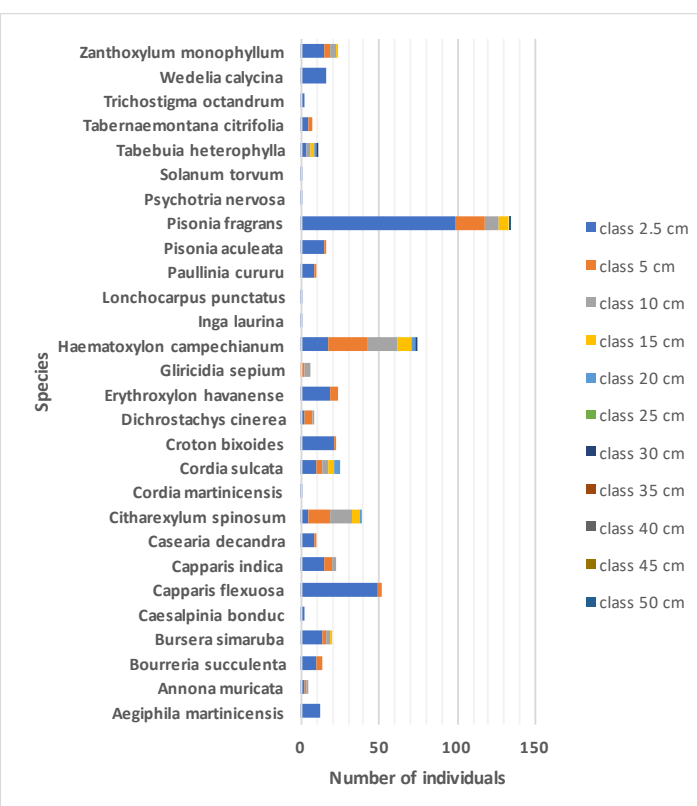

Figure 0.1 : Diametric distribution of living trees (diameters $\geq 2.5 \mathrm{~cm}$; Station $\mathrm{Cl}$ )

Figures 4.1 and 4.2 show the distributions of the diameters and heights of the plant communities in Station C1. Most of the individuals present low measurements for diameter (between 2.5 and $5 \mathrm{~cm}$ ) and height (1 to $8 \mathrm{~m}$ ) (Figures 4.1 and 4.2 ) although some mature trees with high biomass measurements were also recorded: 10 to 30 centimetres in diameter and with heights of between 25 and 35 metres.

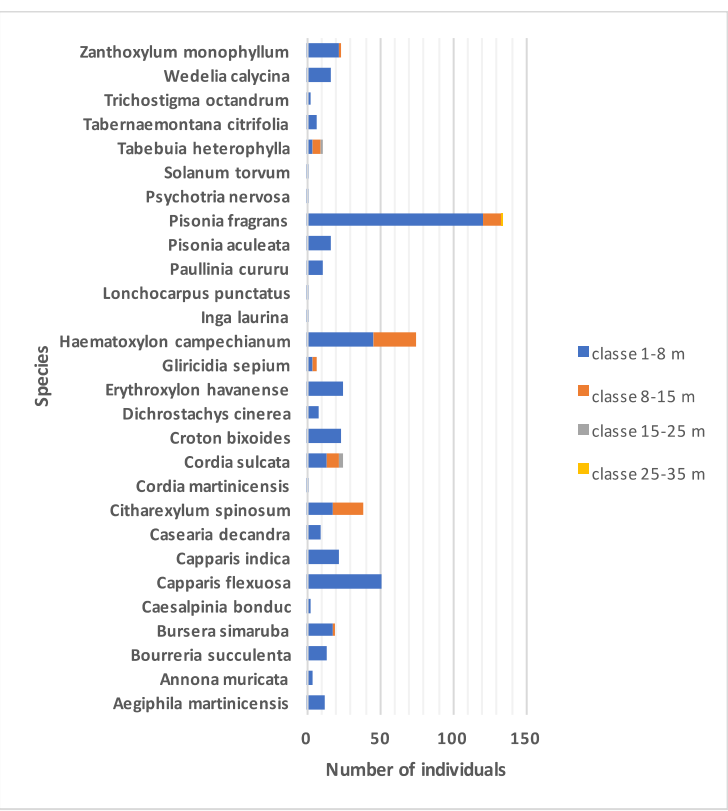

Figure 0.2 : Height distribution of living trees (heights $\geq 1.3 \mathrm{~m} ;$ Station C1)

Haematoxylon campechianum presents the highest indices of distribution and dominance. Its population belongs to a past formation characterised by a small number of individuals of large sections (between 2.5 and $30 \mathrm{~cm}$ ) (Figure 4.1).

Given the number of individuals and their distribution within the station, Pisonia fragrans is therefore the most competitive species in this station.

Station C3

Table 0.2 : The main ecological and structural parameters (Station C3)

\begin{tabular}{|c|c|c|c|c|c|c|c|c|}
\hline Rank & Species C3 & fa & fr & $\begin{array}{l}\text { Number of individuals per species } \\
\text { excluding regenerations and dead trees }\end{array}$ & $\begin{array}{l}\text { Density } \\
\left(\text { ind } / \mathbf{m}^{2}\right)\end{array}$ & Id & $\begin{array}{l}\text { Total basal area } \\
\text { per species }\end{array}$ & ID \\
\hline 1 & $\begin{array}{l}\text { Citharexylum } \\
\text { spinosum }\end{array}$ & 5 & $100 \%$ & 27 & 0.054 & 0.054 & 0.4045 & $2.1842 \mathrm{E}-02$ \\
\hline 2 & Bursera simaruba & 5 & $100 \%$ & 22 & 0.044 & 0.044 & 0.2626 & $1.1555 \mathrm{E}-02$ \\
\hline 3 & $\begin{array}{l}\text { Lonchocarpus } \\
\text { punctatus }\end{array}$ & 4 & $100 \%$ & 18 & 0.036 & 0.0288 & 0.269 & 7.7472E-03 \\
\hline 28 & Dichrostachys cinerea & 1 & $20 \%$ & 1 & 0.002 & 0.0004 & 0.0005 & $1.9635 \mathrm{E}-07$ \\
\hline
\end{tabular}

Absolute frequency $(\mathrm{fa})=$ presence of the species in the different quadrats; Relative frequency $($ fr $)=A b s o l u t e$ frequency / by the number of quadrats; Density = number of individuals / survey area; Index of distribution (Id) = Relative Frequency * Density; Index of dominance $(I D)=$ Index of distribution * basal area

It is a secondary sylvatic to sylvatic young evergreen seasonal tropical forest formation of lower horizon and xeric facies. Citharexylum spinosum, Bursera simaruba and Lonchocarpus punctatus are the most prominent species in the plant cortege. They present very high basal area measurements, which explains their high indices of dominance. The plant matrix consists mainly of young individuals of sections not exceeding 5 centimetres and 8 metres tall, and some mature individuals (Erythroxylon havanense, Casearia decandra, Bourreria succulenta, Acacia tenuifolia and Acacia retusa) with high biomass measurements. The diametric classes of these species are relatively high (sections up to $30 \mathrm{~cm}$ ) (Figure 4.3).

A single individual of Dichrostachys cinerea with a small diameter $(2.5 \mathrm{~cm})$ was surveyed in the station. The latter was observed at the edge of the area inventoried. 
Some Aspects of the Ecology of a Potentially Invasive Species in Martinique: The Case of Dichrostachys cinerea

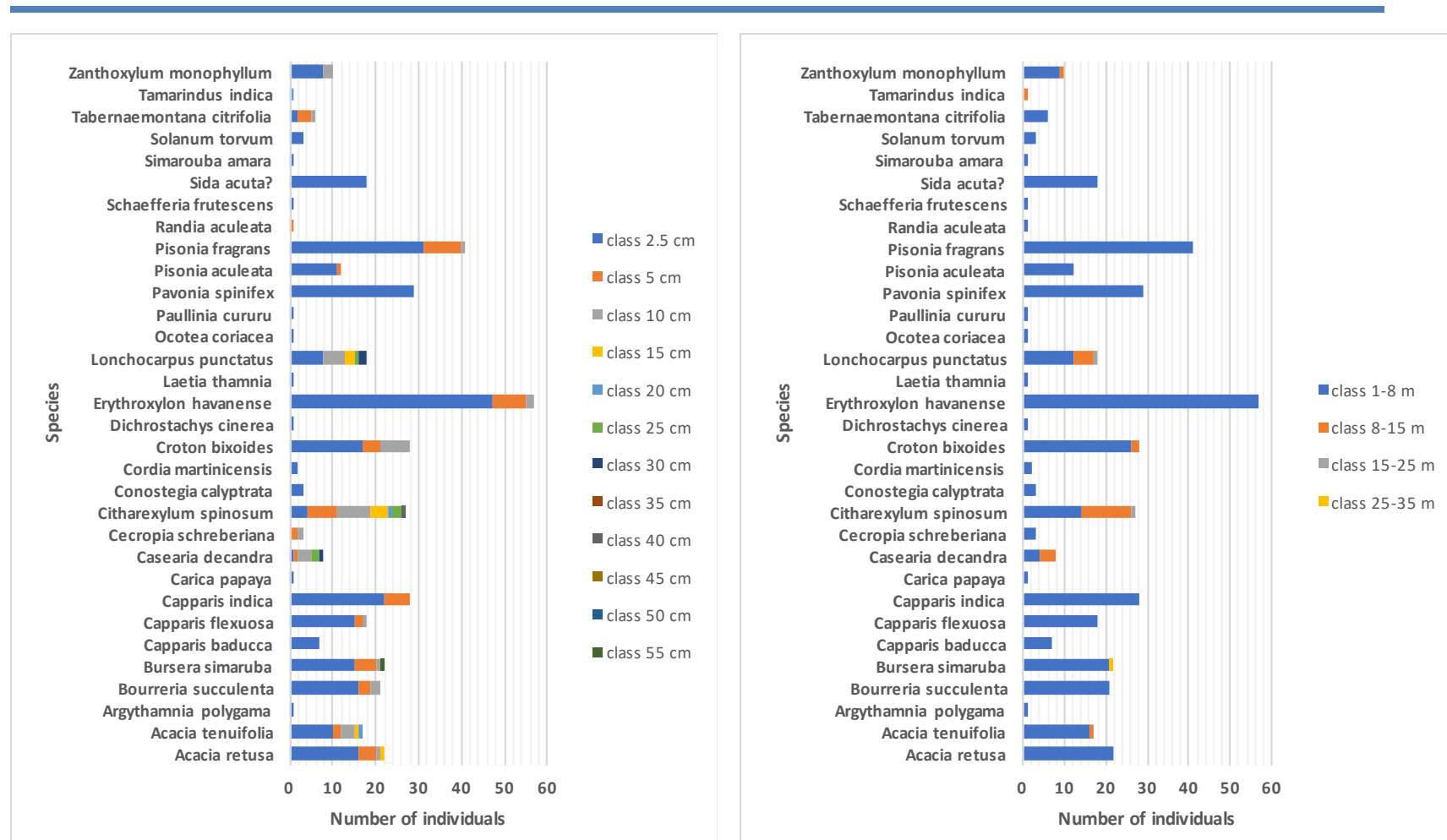

Figure 0.3 : Diametric distribution of living trees (diameters $\geq 2.5 \mathrm{~cm}$; Station $\mathrm{C3}$ )

Figure 0.4 : Height distribution of living trees (heights $\geq 1.3 \mathrm{~m} ;$ Station $\mathrm{C} 3$ )

\section{General summary}

In both cases presented here (stations $\mathrm{C} 1$ and $\mathrm{C} 3$ ), Dichrostachys cinerea is a marginal species. It fails to install itself and to develop its regenerations in secondary sylvatic formations. The few individuals identified (nine in total) in both stations present low measurements for diameter and height. They were found at the edge of the inventory areas. The plant cortege consisted mainly of bushes, with the exception of some woody plants, which have almost

reached their optimal level of morphogenetic development with diameters measuring up to $55 \mathrm{~cm}$ (Figures 4.3 and 4.4). These plant formations are sufficiently structured (closed) so as to prevent the Dichrostachys cinerea from extending its regenerations.

\section{$1.4 \quad$ Average dominance \\ Station V1}

Table 0.3 : The main ecological and structural parameters (Station V1)

\begin{tabular}{|c|c|c|c|c|c|c|c|c|}
\hline Rank & Species V1 & fa & fr & $\begin{array}{l}\text { Number of individuals per species } \\
\text { excluding regenerations and dead trees }\end{array}$ & $\begin{array}{l}\text { Density } \\
\left(\text { ind } / \mathbf{m}^{2}\right)\end{array}$ & Id & $\begin{array}{l}\text { Total basal area } \\
\text { per species }\end{array}$ & ID \\
\hline 1 & Pisonia fragrans & 8 & $100 \%$ & 193 & 0.2413 & 0.2413 & 0.3824 & $9.23 \mathrm{E}-02$ \\
\hline 2 & $\begin{array}{l}\text { Acanthocereus } \\
\text { tetragonus }\end{array}$ & 8 & $100 \%$ & 147 & 0.1838 & 0.1838 & 0.2798 & $5.14 \mathrm{E}-02$ \\
\hline 3 & $\begin{array}{l}\text { Zanthoxylum } \\
\text { monophyllum }\end{array}$ & 8 & $100 \%$ & 45 & 0.0563 & 0.0563 & 0.3794 & $2.13 \mathrm{E}-02$ \\
\hline 4 & Capparis indica & 8 & $100 \%$ & 108 & 0.1350 & 0.1350 & 0.0751 & $1.01 \mathrm{E}-02$ \\
\hline 5 & Erythroxylon havanense & 8 & $100 \%$ & 56 & 0.0700 & 0.0700 & 0.1443 & $1.01 \mathrm{E}-02$ \\
\hline 14 & Dichrostachys cinerea & 4 & $50 \%$ & 11 & 0.0138 & 0.0069 & 0.0157 & $1.08 \mathrm{E}-04$ \\
\hline
\end{tabular}

Absolute frequency $(\mathrm{fa})=$ presence of the species in the different quadrats; Relative frequency (fr) $=$ Absolute frequency / by the number of quadrats; Density = number of individuals / survey area; Index of distribution (Id) = Relative Frequency * Density; Index of dominance $(I D)=$ Index of distribution * basal area

It is a seasonal tropical evergreen formation of lower horizon and xeric facies in the secondary presylvatic stage. The dominant cortege is composed of - in order of ecological significance - Pisonia fragrans and Acanthocereus tetragonus. These species present a large number of individuals (193 individuals for Pisonia fragrans and 147 for Acanthocereus tetragonus), and relatively large basal area and distribution measurements (Table 4.3). Acanthocereus tetragonus is a species indicative of 
Some Aspects of the Ecology of a Potentially Invasive Species in Martinique: The Case of Dichrostachys cinerea

highly perturbed xeric areas. Its significant dominance and its abundance in the plant community attest to the extensive degradation of the site. The plant stand is composed of regenerations, young units and a few (seven) mature individuals of large sections (up to $45 \mathrm{~cm}$ in diameter for Bursera simaruba or Citharexylum spinosum).

Under this matrix, species at a more advanced stage of plant dynamics such as Bunchosia glandulosa,
Cordia collococca, Meliococcus bijugatus and Randia nitida regenerate. The height distribution is mostly between 1 and 8 metres, with few individuals exceeding 8 metres in height (Figure 4.6).

Dichrostachys cinerea is slightly more distributed in the station (eleven individuals surveyed) (Table 4.3). Its population is marked by individuals of larger sections up to 10 centimetres (Figure 4.5).

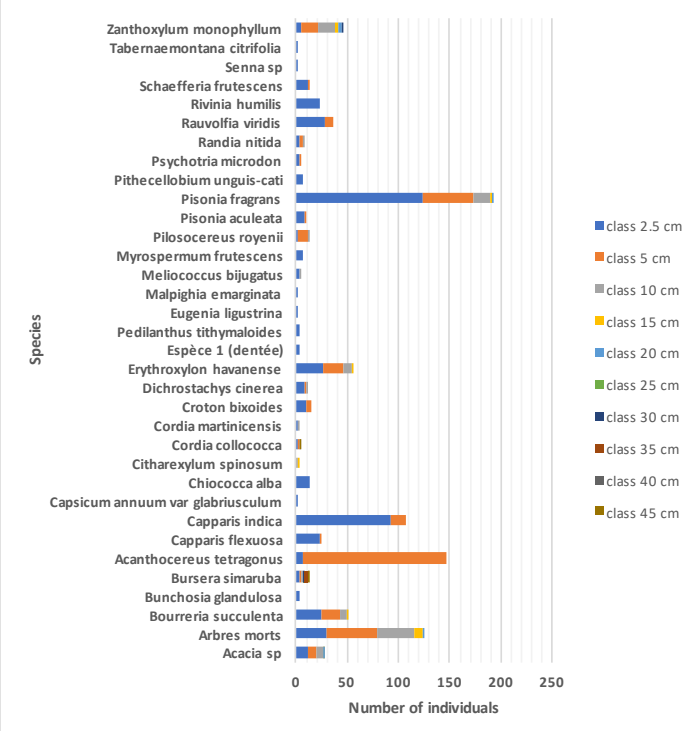

Figure 0.5 : Diametric distribution of living trees (diameters $\geq 2.5 \mathrm{~cm}$; Station V1)

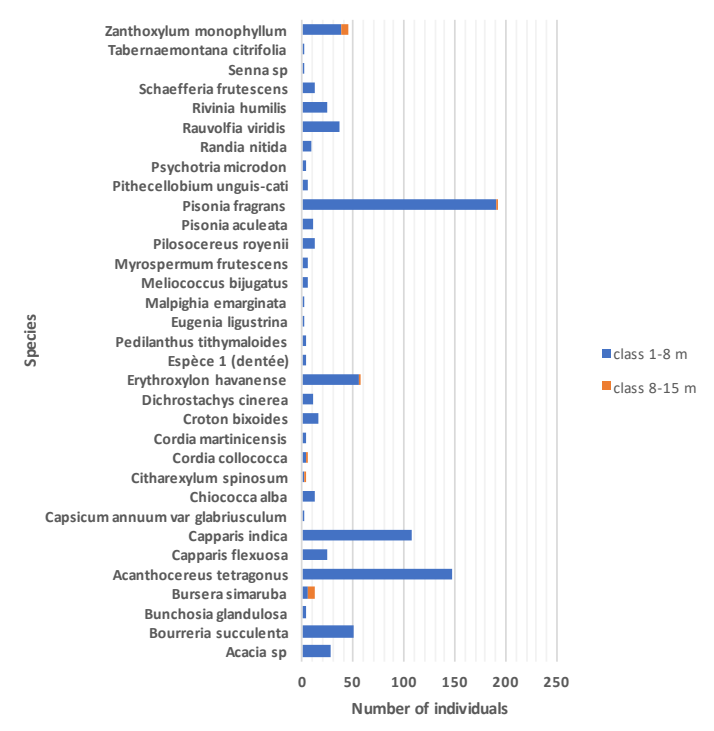

Figure 0.6 : Height distribution of living trees (heights $\geq 1.3 \mathrm{~m} ;$ Station V1)

Station V2

Table 0.4 : The main ecological and structural parameters (Station V2)

\begin{tabular}{|c|c|c|c|c|c|c|c|c|}
\hline Rank & Species V2 & fa & fr & $\begin{array}{l}\text { Number of individuals per species } \\
\text { excluding regenerations and dead trees }\end{array}$ & $\begin{array}{l}\text { Density } \\
\left(\text { ind } / \mathbf{m}^{2}\right)\end{array}$ & Id & $\begin{array}{l}\text { Total basal area } \\
\text { per species }\end{array}$ & ID \\
\hline \multirow[t]{2}{*}{1} & Acanthocereus & & & & & & & \\
\hline & tetragonus & 7 & $100 \%$ & 124 & 0.3543 & 0.3543 & 0.2734 & 9.69E-02 \\
\hline 2 & Pisonia fragrans & 7 & $100 \%$ & 67 & 0.1914 & 0.1914 & 0.2538 & $4.86 \mathrm{E}-02$ \\
\hline 3 & $\begin{array}{l}\text { Zanthoxylum } \\
\text { monophyllum }\end{array}$ & 6 & $86 \%$ & 43 & 0.1229 & 0.1053 & 0.1865 & $1.96 \mathrm{E}-02$ \\
\hline 4 & Erythroxylum havanense & 7 & $100 \%$ & 46 & 0.1314 & 0.1314 & 0.1203 & $1.58 \mathrm{E}-02$ \\
\hline 10 & Dichrostachys cinerea & 3 & $43 \%$ & 13 & 0.0371 & 0.0159 & 0.0182 & $2.89 \mathrm{E}-04$ \\
\hline
\end{tabular}

Absolute frequency $(\mathrm{fa})=$ presence of the species in the different quadrats; Relative frequency $(f r)=$ Absolute frequency / by the number of quadrats; Density = number of individuals / survey area; Index of distribution (Id) = Relative Frequency * Density; Index of dominance $(I D)=$ Index of distribution * basal area

This station presents ecological similarities to the previous station (station V1). The most predominant species are - in order of ecological significance Acanthocereus tetragonus and Pisonia fragrans. They present relatively high distribution and basal area measurements. The plant matrix is composed of a few mature individuals with relatively high section and height measurements, such as Zanthoxylum monophyllum, Erythroxylon havanense, Bourreria succulenta and Acacia sp. In addition to these individuals, this matrix shows very low measurements for diameter (between 2.5 and $5 \mathrm{~cm}$ ) and height (between 1 and $8 \mathrm{~m}$ ) (Figures 4.7 and 4.8). 
Some Aspects of the Ecology of a Potentially Invasive Species in Martinique: The Case of Dichrostachys cinerea

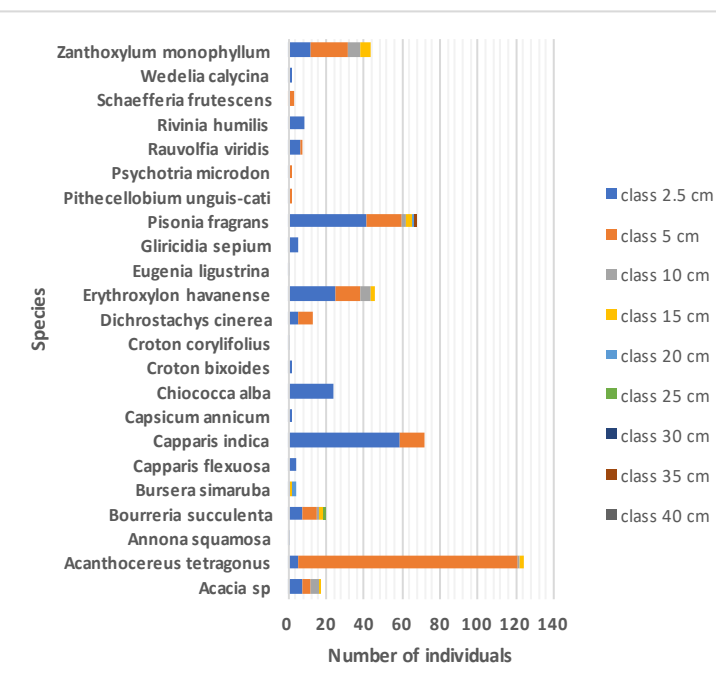

Figure 0.7 : Diametric distribution of living trees (diameters $\geq 2.5 \mathrm{~cm} ;$ Station V2)

\section{Station V3}

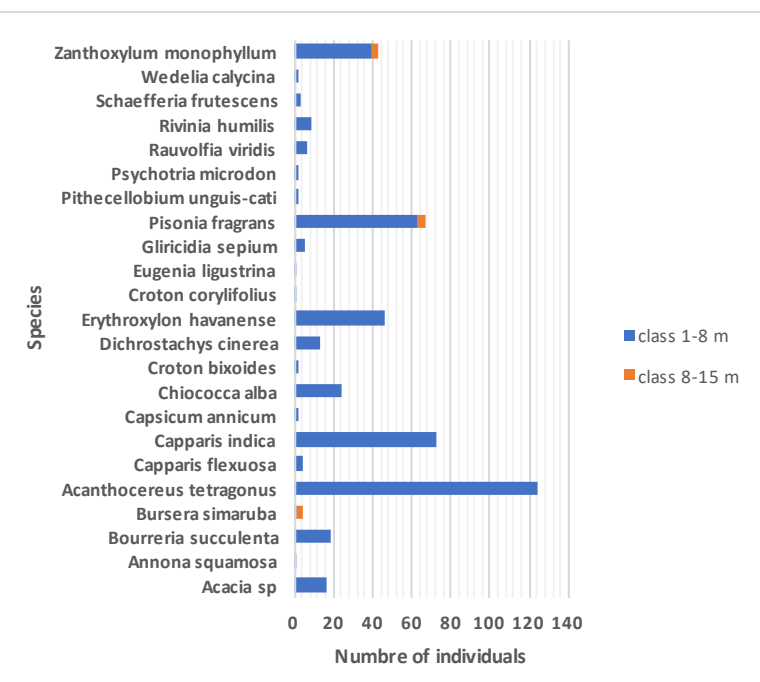

Figure 0.8: Height distribution of living trees (heights $\geq 1.3 \mathrm{~m}$; Station V2)

Table 0.5 : The main ecological and structural parameters (Station V3)

\begin{tabular}{|c|c|c|c|c|c|c|c|c|}
\hline Rank & Species V3 & fa & fr & $\begin{array}{l}\text { Number of individuals per species } \\
\text { excluding regenerations and dead trees }\end{array}$ & $\begin{array}{l}\text { Density } \\
\left(\text { ind } / \mathbf{m}^{2}\right)\end{array}$ & Id & $\begin{array}{l}\text { Total basal area } \\
\text { per species }\end{array}$ & ID \\
\hline 1 & Croton bixoides & 7 & $100 \%$ & 85 & 0.2429 & 0.2429 & 0.05792 & $1.4067 \mathrm{E}-02$ \\
\hline 2 & Pisonia fragrans & 7 & $100 \%$ & 15 & 0.0429 & 0.0429 & 0.1242 & $5.3225 \mathrm{E}-03$ \\
\hline 3 & Erythroxylum havanense & 7 & $100 \%$ & 38 & 0.1086 & 0.1086 & 0.0285 & $3.0911 \mathrm{E}-03$ \\
\hline 4 & Dichrostachys cinerea & 5 & $71 \%$ & 18 & 0.0514 & 0.0367 & 0.0614 & $2.2540 \mathrm{E}-03$ \\
\hline
\end{tabular}

Absolute frequency $(\mathrm{fa})=$ presence of the species in the different quadrats; Relative frequency $($ fr $)=A b s o l u t e$ frequency / by the number of quadrats; Density = number of individuals / survey area; Index of distribution $($ Id $)=$ Relative Frequency * Density; Index of dominance $(I D)=$ Index of distribution * basal area

It is a seasonal tropical evergreen formation of lower horizon and xeric facies at pre-forest to bush stage. The predominant species are - in order of ecological significance - Croton bixoides, Pisonia fragrans and Erythroxylum havanense. In this station, the floristic composition is characterised for the most part by individuals with very small measurements for

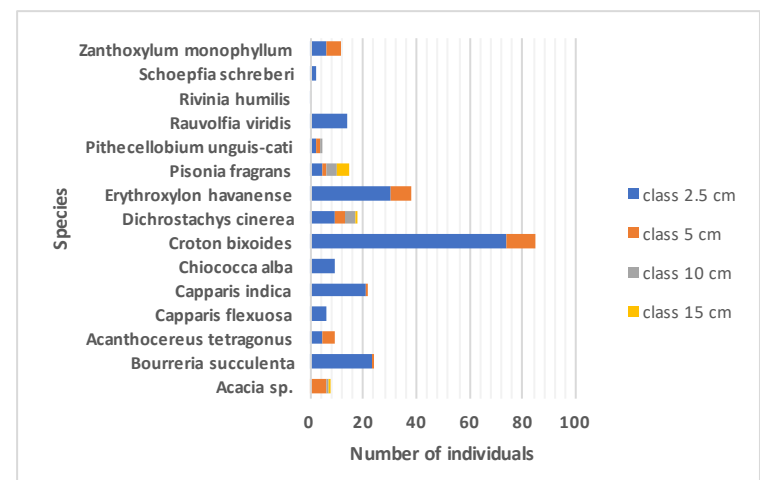

Figure 0.9 : Diametric distribution of living trees (diameters $\geq 2.5 \mathrm{~cm}$; Station V3)

$\underline{\text { Station V4 }}$ sections $(2.5 \mathrm{~cm}$ on average) and height, ranging between 1 and 8 metres.

Dichrostachys cinerea is more predominant $(71 \%)$ in this station (Table 4.5). Its individuals present relatively large sections measuring 2.5 or even 15 centimetres.

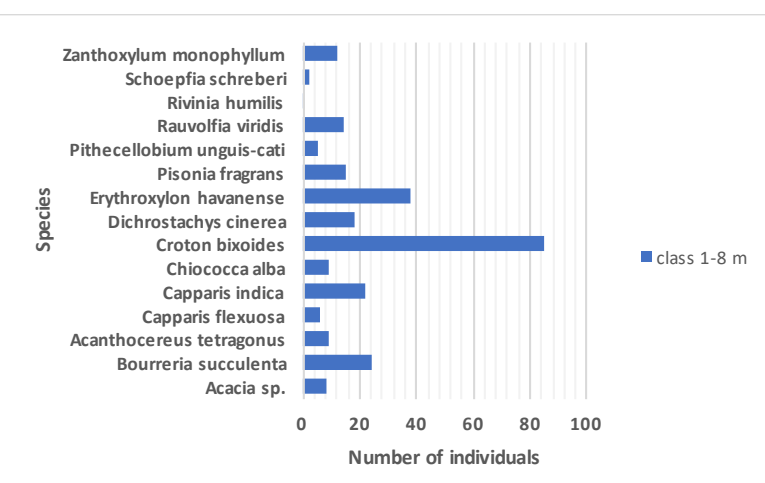

Figure $0.10:$ Height distribution of living trees (heights $\geq 1.3 \mathrm{~m}$; Station V3) 
Some Aspects of the Ecology of a Potentially Invasive Species in Martinique:

The Case of Dichrostachys cinerea

Table 0.6 : The main ecological and structural parameters (Station V4)

\begin{tabular}{|c|c|c|c|c|c|c|c|c|}
\hline $\begin{array}{l}\text { Ran } \\
\mathbf{k}\end{array}$ & Species V4 & fa & fr & $\begin{array}{l}\text { Number of individuals per } \\
\text { species excluding regenerations } \\
\text { and dead trees }\end{array}$ & $\begin{array}{l}\text { Density } \\
\text { (ind/m²) }\end{array}$ & Id & $\begin{array}{lr}\text { Total } & \text { basal } \\
\text { area } & \text { per } \\
\text { species } & \\
\end{array}$ & ID \\
\hline 1 & $\begin{array}{l}\text { Dichrostachys } \\
\text { cinerea }\end{array}$ & 7 & $\begin{array}{l}78 \\
\%\end{array}$ & 18 & 0.04 & $\begin{array}{l}0.031 \\
1\end{array}$ & 0.0383 & $\begin{array}{l}1.19 \mathrm{E}- \\
03\end{array}$ \\
\hline 2 & Croton bixoides & 6 & $\begin{array}{l}67 \\
\%\end{array}$ & 24 & 0.053 & $\begin{array}{l}0.035 \\
6\end{array}$ & 0.0132 & $\begin{array}{l}4.71 \mathrm{E}- \\
04\end{array}$ \\
\hline 3 & $\begin{array}{l}\text { Zanthoxylum } \\
\text { monophyllum }\end{array}$ & 3 & $\begin{array}{l}33 \\
\%\end{array}$ & 9 & 0.02 & $\begin{array}{l}0.006 \\
7 \\
\end{array}$ & 0.0074 & $\begin{array}{l}4.91 \mathrm{E}- \\
05\end{array}$ \\
\hline 4 & $\begin{array}{l}\text { Erythroxylon } \\
\text { havanense }\end{array}$ & 5 & $\begin{array}{l}56 \\
\% \\
\end{array}$ & 7 & 0.0156 & $\begin{array}{l}0.008 \\
6 \\
\end{array}$ & 0.0034 & $\begin{array}{l}2.97 \mathrm{E}- \\
05\end{array}$ \\
\hline 5 & $\begin{array}{l}\text { Bourreria } \\
\text { succulenta }\end{array}$ & 3 & $\begin{array}{l}33 \\
\%\end{array}$ & 4 & 0.0089 & 0.003 & 0.0064 & $\begin{array}{l}1.89 \mathrm{E}- \\
05\end{array}$ \\
\hline
\end{tabular}

Absolute frequency $(\mathrm{fa})=$ presence of the species in the different quadrats; Relative frequency $($ fr $)=$ Absolute frequency / by the number of quadrats; Density = number of individuals / survey area; Index of distribution $($ Id $)=$ Relative frequency * Density; Index of dominance $(I D)=$ Index of distribution $*$ basal area

This plant community is a seasonal tropical evergreen formation of lower horizon and xeric facies at preforest to bush stage.

The dominant cortege consists of - in order of ecological significance - Dichrostachys cinerea and
Croton bixoides. In view of its ecological functioning within the plant matrix, Dichrostachys cinerea is considered a dynamic inhibitor (Joseph, 2009). This reflects the fact that the plant matrix is essentially composed of species with very low height and diameter measurements (Figures 4.11 and 4.12).

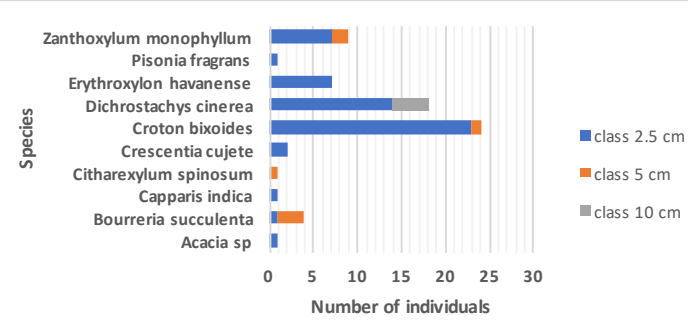

Figure 0.11 : Diametric distribution of living trees (diameters $\geq 2.5 \mathrm{~cm}$; Station V4)

Station V5

Table 0.7 : The main ecological and structural parameters (Station V5)

\begin{tabular}{|c|c|c|c|c|c|c|c|c|}
\hline Row & Species V5 & fa & fr & $\begin{array}{l}\text { Number of individuals per species } \\
\text { excluding regenerations and dead trees }\end{array}$ & $\begin{array}{l}\text { Density } \\
\text { (ind } / \mathbf{m}^{2} \text { ) }\end{array}$ & Id & $\begin{array}{l}\text { Total basal area } \\
\text { per species }\end{array}$ & ID \\
\hline 1 & Croton bixoides & 7 & $88 \%$ & 120 & 0.3 & 0.2625 & 0.0825 & $2.1648 \mathrm{E}-02$ \\
\hline 2 & Pisonia fragrans & 8 & $100 \%$ & 16 & 0.04 & 0.04 & 0.2322 & $9.2873 \mathrm{E}-03$ \\
\hline 3 & Acacia $s p$ & 4 & $50 \%$ & 16 & 0.04 & 0.02 & 0.1193 & $2.3856 \mathrm{E}-03$ \\
\hline 8 & $\begin{array}{l}\text { Dichrostachys } \\
\text { cinerea }\end{array}$ & 5 & $63 \%$ & 12 & 0.03 & 0.01875 & 0.0074 & $1.3806 \mathrm{E}-04$ \\
\hline
\end{tabular}

Absolute frequency $(\mathrm{fa})=$ presence of the species in the different quadrats; Relative frequency $(f r)=A b s o l u t e$ frequency / by the number of quadrats; Density = number of individuals / survey area; Index of distribution (Id) = Relative frequency * Density; Index of dominance $(I D)=$ Index of distribution * basal area

This seasonal tropical evergreen floristic unit of lower horizon and xeric facies at the pre-forest to bush stage is dominated by a large population of Croton bixoides (120 individuals per species excluding regenerations and dead trees), most of whose individuals have sections measuring 2.5 centimetres (i.e. $64.7 \%$ and $35.3 \%$ have diameters of $5 \mathrm{~cm}$ ) (Table 4.8). This is with the exception of some mature individuals (Pisonia fragrans, Bourreria succulenta and Acacia sp) from the station that belong to past formations of earlier relicts and which show much larger section measurements. The other, younger individuals present small sections (2.5 to 5 $\mathrm{cm}$ ) and small sizes (less than $8 \mathrm{~m}$ ) (Figures 4.13 and 4.14). 
Some Aspects of the Ecology of a Potentially Invasive Species in Martinique:

The Case of Dichrostachys cinerea

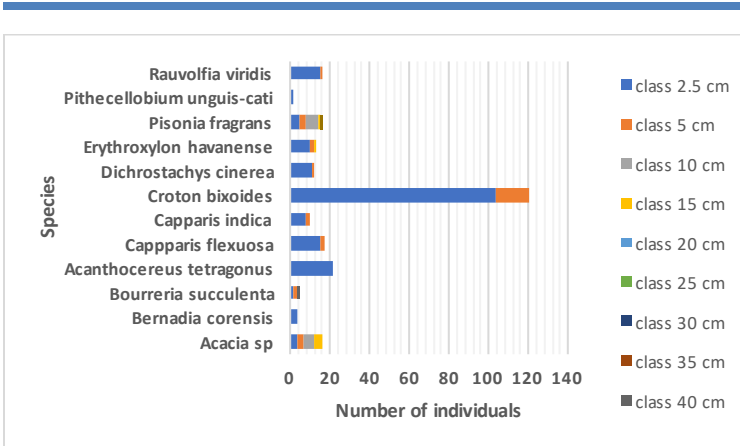

Figure 0.13 : Diametric distribution of living trees (diameters $\geq 2.5 \mathrm{~cm}$; Station V5)

Station V6

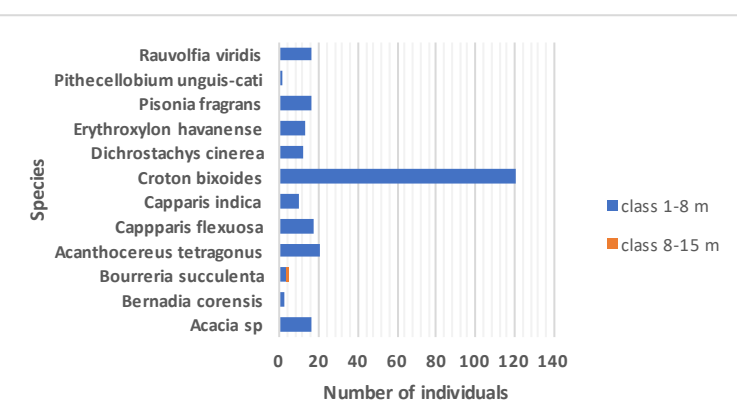

Figure 0.14 : Height distribution of living trees (heights $\geq 1.3 \mathrm{~m}$; Station V5)

Table 0.8: The main ecological and structural parameters (Station V6)

\begin{tabular}{|c|c|c|c|c|c|c|c|c|}
\hline Rank & Species V6 & fa & fr & $\begin{array}{l}\text { Number of individuals per species } \\
\text { excluding regenerations and dead trees }\end{array}$ & $\begin{array}{l}\text { Density } \\
\text { (ind/m²) }\end{array}$ & Id & $\begin{array}{l}\text { Total basal area } \\
\text { per species }\end{array}$ & ID \\
\hline 1 & Acacia $s p$ & 2 & $40 \%$ & 3 & 0.012 & 0.0048 & 0.0059 & $2.83 \mathrm{E}-05$ \\
\hline 2 & Capparis indica & 2 & $40 \%$ & 5 & 0.02 & 0.008 & 0.0025 & $1.96 \mathrm{E}-05$ \\
\hline 3 & $\begin{array}{l}\text { Dichrostachys } \\
\text { cinerea }\end{array}$ & 4 & $80 \%$ & 3 & 0.012 & 0.0096 & 0.0015 & $1.41 \mathrm{E}-05$ \\
\hline 7 & Pisonia fragrans & 2 & $40 \%$ & 1 & 0.004 & 0.0016 & 0.0079 & $1.26 \mathrm{E}-05$ \\
\hline
\end{tabular}

Absolute frequency $(\mathrm{fa})=$ presence of the species in the different quadrats; Relative frequency $(\mathrm{fr})=$ Absolute frequency / by the number of quadrats; Density = number of individuals / survey area; Index of distribution (Id) = Relative frequency * Density; Index of dominance $(I D)=$ Index of distribution * basal area

The plant stand of this station is composed of individuals with very low height (less than $8 \mathrm{~m}$ ) and section $(2.5$ or even $5 \mathrm{~cm})$ measurements, with the exception of a few units (3) of the dominant species of the station, Acacia sp, which present a large basal area measurement (Table 4.9).
Dichrostachys cinerea is widely distributed in this station $(80 \%)$ but presents young individuals which are small in size (Figures 4.15 and 4.16).

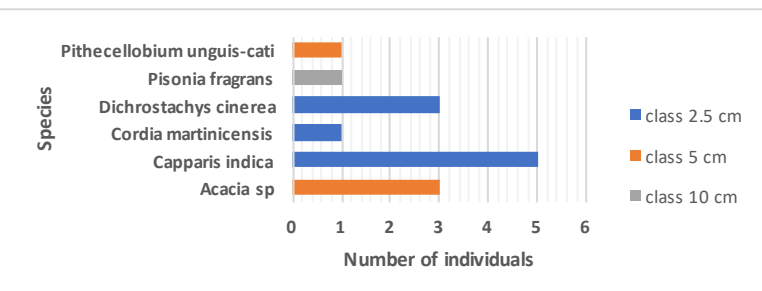

Figure 0.15 : Diametric distribution of living trees (diameters $\geq 2.5 \mathrm{~cm}$; Station V6)

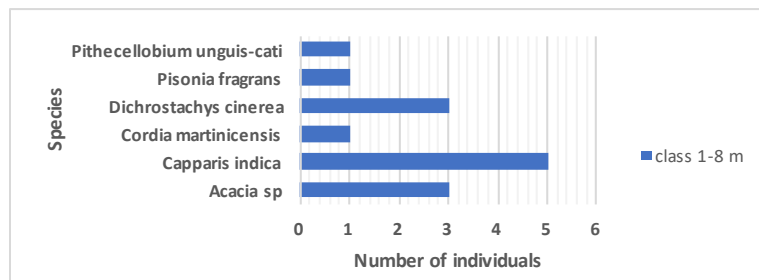

Figure 0.16: Height distribution of living trees (heights $\geq 1.3 \mathrm{~m}$; Station V6)

\section{Station V9}

Table 0.9 : The main ecological and structural parameters (Station V9)

\begin{tabular}{|c|c|c|c|c|c|c|c|c|}
\hline Rank & Species V9 & fa & fr & $\begin{array}{l}\text { Number of individuals per species } \\
\text { excluding regenerations and dead trees }\end{array}$ & $\begin{array}{l}\text { Density } \\
\text { (ind } / \mathbf{m}^{2} \text { ) }\end{array}$ & Id & $\begin{array}{l}\text { Total basal area } \\
\text { per species }\end{array}$ & ID \\
\hline 1 & Bourreria succulenta & 5 & $100 \%$ & 44 & 0.088 & 0.088 & 0.1237 & $1.0886 \mathrm{E}-02$ \\
\hline 2 & Zanthoxylum monophyllum & 5 & $100 \%$ & 35 & 0.07 & 0.07 & 0.1404 & 9.8273E-03 \\
\hline 3 & Croton bixoides & 4 & $80 \%$ & 57 & 0.114 & 0.0912 & 0.08689 & 7.9239E-03 \\
\hline 6 & Acacia sp & 3 & $60 \%$ & 19 & 0.038 & 0.0228 & 0.1134 & $2.5853 \mathrm{E}-03$ \\
\hline 7 & Dichrostachys cinerea & 4 & $80 \%$ & 33 & 0.066 & 0.0528 & 0.0339 & $1.7884 \mathrm{E}-03$ \\
\hline
\end{tabular}

Absolute frequency $(\mathrm{fa})=$ presence of the species in the different quadrats; Relative frequency $($ fr $)=A b s o l u t e$ frequency / by the number of quadrats; Density = number of individuals / survey area; Index of distribution (Id) = Relative frequency * Density; Index of dominance $(I D)=$ Index of distribution * basal area 
From the ecological point of view, this station is very similar to the station described previously (station V3). It describes a seasonal tropical evergreen formation of lower horizon and xeric facies at the presylvatic to bush stage. However, the predominant cortege is not the same as that of station V3. Bourreria succulenta, Zanthoxylum monophyllum, Croton bixoides and Erythroxylon havanense are the predominant species of the station, in order of ecological significance. These four species are all heliophilous species characterised by individuals presenting large section measurements (up to $15 \mathrm{~cm}$ ) (Figure 4.5). In addition to these individuals, Acacia

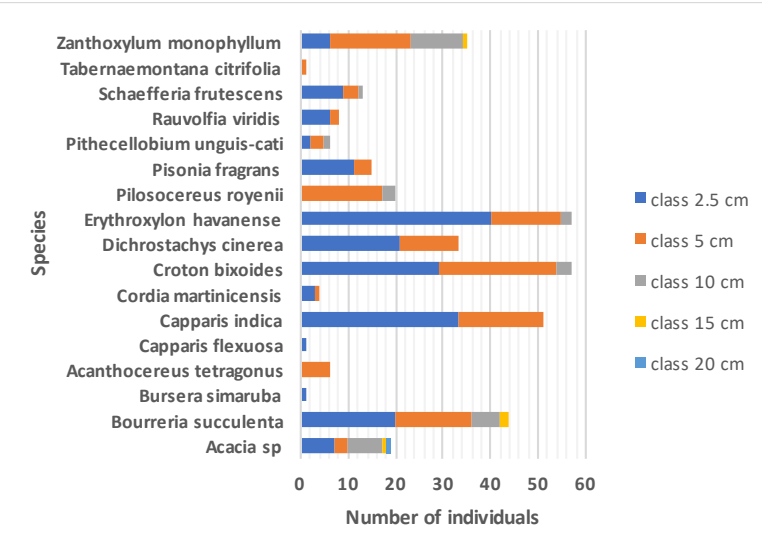

Figure 0.17 : Diametric distribution of living trees (diameters $\geq 2.5 \mathrm{~cm}$; Station V1)

\section{General summary}

The distribution of the species Dichrostachys cinerea within the quadrats of the previously described stations is high. 108 individuals were counted. The plant stratum of these stations (V1, V2, V3, V4, V5, V6 and V9) is discontinuous. It is dominated by woody plants (bushes and trees) of various sizes and rarely exceeding 8 metres in height (Figures 4.6, 4.8, $4.10,4.12,4.14,4.16$ and 4.18). It included heliophilous species with large sections such as Bourreria succulenta, Acacia sp and Pisonia fragrans. These species tend to develop in gaps and $s p$ also presents high diametric distributions (up to 20 $\mathrm{cm}$ ), but its small population means it is not part of the species of the dominant cortege. The plant stand of the station is marked by individuals with low measurements for diameter (between 2.5 and $5 \mathrm{~cm}$ ) and height, not exceeding 8 metres (Figure 4.6).

Dichrostachys cinerea is distributed to a much greater extent in this station $(80 \%)$ and presents a larger population with small diameters and heights (Figures 4.5 and 4.6).

Table 0.10: The main ecological and structural parameters (Station V7)

\begin{tabular}{|c|c|c|c|c|c|c|c|c|}
\hline Rank & Species V7 & fa & fr & $\begin{array}{l}\text { Number of individuals per species } \\
\text { excluding regenerations and dead trees }\end{array}$ & $\begin{array}{l}\text { Density } \\
\left(\text { ind } / \mathbf{m}^{2}\right)\end{array}$ & Id & $\begin{array}{l}\text { Total basal area } \\
\text { per species }\end{array}$ & ID \\
\hline 1 & Dichrostachys cinerea & 6 & $100 \%$ & 114 & 0.4750 & 0.4750 & 0.0854 & $4.0571 \mathrm{E}-02$ \\
\hline 2 & Erythroxylon havanense & 1 & $17 \%$ & 3 & 0.0125 & 0.0021 & 0.0059 & $1.2272 \mathrm{E}-05$ \\
\hline 3 & Capparis flexuosa & 1 & $17 \%$ & 1 & 0.0042 & 0.0007 & 0.0020 & $1.3635 \mathrm{E}-06$ \\
\hline
\end{tabular}

Absolute frequency $(\mathrm{fa})=$ presence of the species in the different quadrats; Relative frequency $($ fr $)=$ Absolute frequency / by the number of quadrats; Density = number of individuals / survey area; Index of distribution (Id) = Relative frequency * Density; Index of dominance $(I D)=$ Index of distribution * basal area

This plant community is a seasonal tropical evergreen formation of lower horizon and xeric facies at bush stage dominated by a population of Dichrostachys cinerea. Other species of the plant matrix are very marginal (Figures 4.19 and 4.20). They present small sections for a small number of individuals. 94 individuals of class $2.5 \mathrm{~cm}(82.5 \%)$ and 20 individuals of class $5 \mathrm{~cm}$ of Dichrostachus cinerea between 1 and 8 metres high were identified. Its high population reflects a highly degraded station characterised by low biomass individuals. 


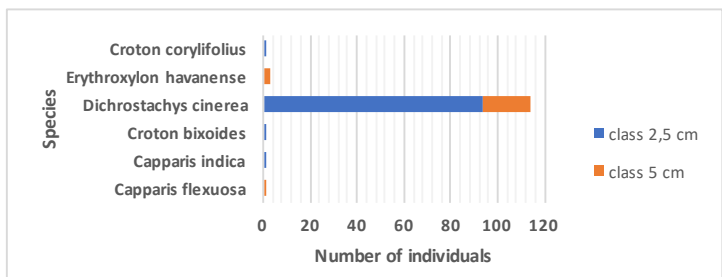

Figure 0.19 : Diametric distribution of living trees (diameters $\geq 2.5 \mathrm{~cm} ;$ Station V7)

$\underline{\text { Station V8 }}$

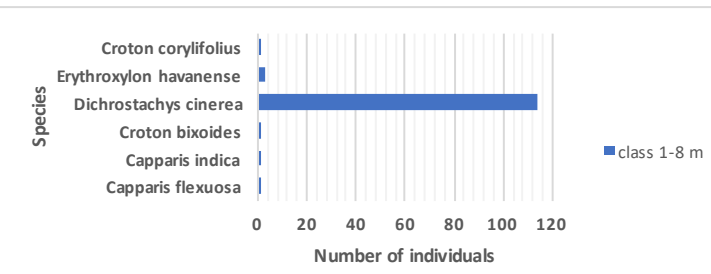

Figure 0.20 : Height distribution of living trees (heights $\geq 1.3 \mathrm{~m} ;$ Station V7)

Table 0.11 : The main ecological and structural parameters (Station V8)

\begin{tabular}{|c|c|c|c|c|c|c|c|c|}
\hline Rank & Species V8 & fa & fr & $\begin{array}{l}\text { Number of individuals per species } \\
\text { excluding regenerations and dead trees }\end{array}$ & $\begin{array}{l}\text { Density } \\
\text { (ind } / \mathbf{m}^{2} \text { ) }\end{array}$ & Id & $\begin{array}{l}\text { Total basal area } \\
\text { per species }\end{array}$ & ID \\
\hline 1 & Dichrostachys cinerea & 7 & $100 \%$ & 158 & 0.5643 & 0.5643 & 0.1556 & $8.7807 \mathrm{E}-02$ \\
\hline 2 & Capparis flexuosa & 4 & $57 \%$ & 12 & 0.0429 & 0.0245 & 0.0162 & $3.9671 \mathrm{E}-04$ \\
\hline 3 & $\begin{array}{l}\text { Pithecellobium unguis- } \\
\text { cati }\end{array}$ & 2 & $29 \%$ & 6 & 0.0214 & 0.006 & 0.0103 & $6.3112 \mathrm{E}-05$ \\
\hline
\end{tabular}

Absolute frequency $(\mathrm{fa})=$ presence of the species in the different quadrats; Relative frequency $($ fr $)=$ Absolute frequency / by the number of quadrats; Density = number of individuals / survey area; Index of distribution (Id) = Relative frequency * Density; Index of dominance $(I D)=$ Index of distribution * basal area

This much degraded station is marked by significant trampling of cattle. The plant cortege is mainly composed of herbaceous plants and regenerations of sylvatic gap species (including Pisonia fragrans and Bursera simaruba). It is a seasonal tropical evergreen formation of lower horizon and xeric facies at the

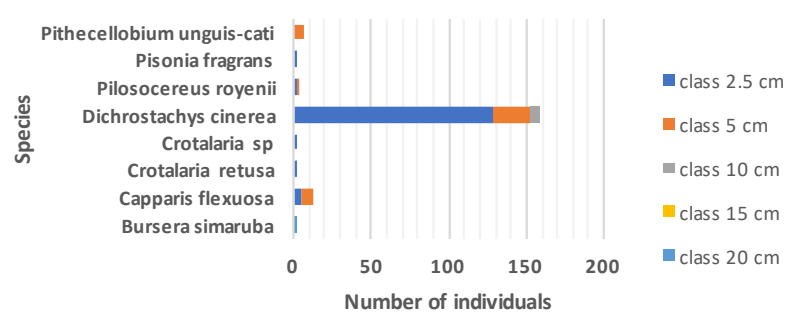

Figure 0.21 : Diametric distribution of living trees (diameters $\geq 2.5 \mathrm{~cm}$; Station V8) bush stage. From an ecological point of view, this station is very similar to the station described previously (station V7). Dichrostachys cinerea is the most competitive species. The other species of the plant cortege, present in very small quantities, have small basal areas (Table 4.12).

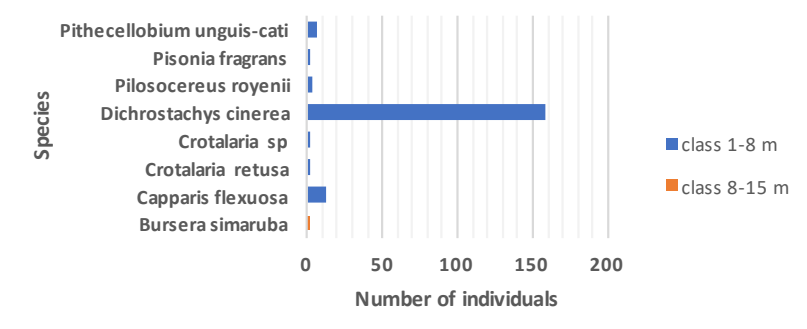

Figure 0.22 : Height distribution of living trees (heights $\geq 1.3 \mathrm{~m}$; Station V8)

\section{$\underline{\text { Station } M 1}$}

Table 0.12 : The main ecological and structural parameters (Station M1)

\begin{tabular}{|c|c|c|c|c|c|c|c|c|}
\hline Rank & Species M1 & fa & fr & $\begin{array}{l}\text { Number of individuals per species } \\
\text { excluding regenerations and dead trees }\end{array}$ & $\begin{array}{l}\text { Density } \\
\text { (ind } / \mathbf{m}^{2} \text { ) }\end{array}$ & Id & $\begin{array}{l}\text { Total basal area } \\
\text { per species }\end{array}$ & ID \\
\hline 1 & Dichrostachys cinerea & 6 & $100 \%$ & 293 & 0.4883 & 0.4883 & 0.16 & $7.8145 \mathrm{E}-02$ \\
\hline 2 & Swietenia aubrevilleana & 6 & $100 \%$ & 195 & 0.325 & 0.325 & 0.5547 & $1.8027 \mathrm{E}-01$ \\
\hline 3 & Tabebuia heterophylla & 6 & $100 \%$ & 49 & 0.0817 & 0.0817 & 0.7103 & $5.8007 \mathrm{E}-02$ \\
\hline 4 & Hippomane mancinella & 4 & $67 \%$ & 16 & 0.0267 & 0.0178 & 1.1648 & $2.0708 \mathrm{E}-02$ \\
\hline
\end{tabular}

Absolute frequency $(\mathrm{fa})=$ presence of the species in the different quadrats; Relative frequency $($ fr $)=$ Absolute frequency / by the number of quadrats; Density = number of individuals / survey area; Index of distribution (Id) = Relative frequency * Density; Index of dominance $(I D)=$ Index of distribution * basal area

This plant community describes a seasonal tropical evergreen formation of lower horizon and xeric facies at the bush stage dominated by the Dichrostachys cinerea population. The sylvatic unit is marked by two phytocenoses at different stages of development. One is characterised by a structured young sylvatic formation indicated by secondary heliophilous species (Citangosphere spinosum, Coccoloba swartzii, Daphnopsis americana, Pisonia fragrans, Swietenia aubrevilleana, Tabebuia heterophylla). The other phytocenosis is marked by regenerations and young units of species associated with the bush 
Some Aspects of the Ecology of a Potentially Invasive Species in Martinique: The Case of Dichrostachys cinerea

stage (Bourreria succulenta, Croton bixoides, Erithalis fruticosa, Erythroxylon havanense and Randia aculeata). This discontinuity of the stratum has enabled the expansion of Dichrostachys cinerea in the vacant spaces of the station.

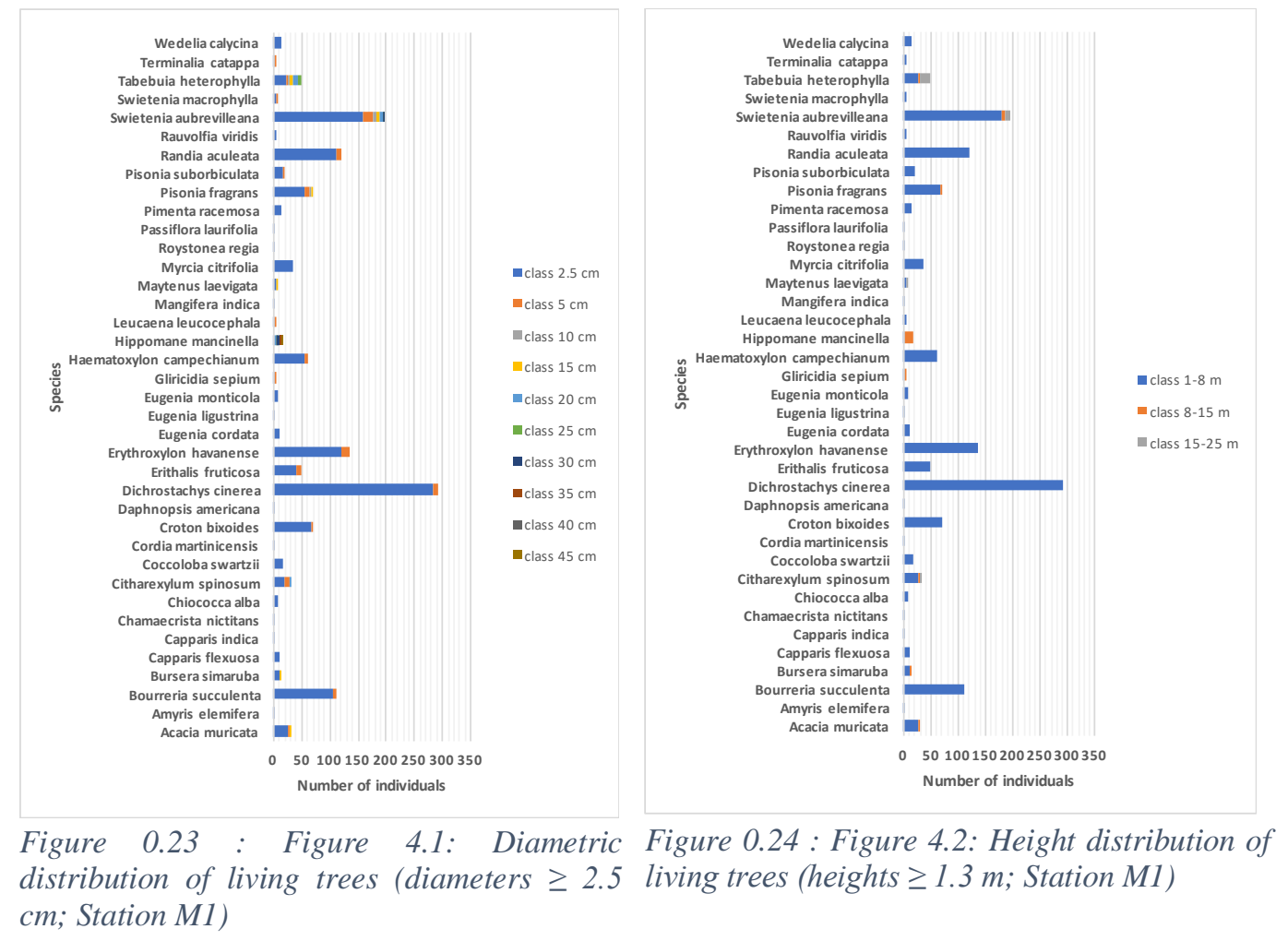

$\underline{\text { Station } M 2}$

Table 0.13 : The main ecological and structural parameters (Station M2)

\begin{tabular}{|c|c|c|c|c|c|c|c|c|}
\hline Rank & Species M2 & fa & fr & $\begin{array}{l}\text { Number of individuals per species } \\
\text { excluding regenerations and dead trees }\end{array}$ & $\begin{array}{l}\text { Density } \\
\left(\text { ind } / \mathbf{m}^{2}\right)\end{array}$ & Id & $\begin{array}{l}\text { Total basal area } \\
\text { per species }\end{array}$ & ID \\
\hline 1 & Dichrostachys cinerea & 8 & $100 \%$ & 80 & 0.1 & 0.1 & 0.0525 & $5.2524 \mathrm{E}-03$ \\
\hline 2 & Thespesia populnea & 6 & $75 \%$ & 46 & 0.0575 & 0.0431 & 0.3525 & $1.5199 \mathrm{E}-02$ \\
\hline 3 & Tabebuia heterophylla & 7 & $87,5 \%$ & 36 & 0.045 & 0.0394 & 0.403 & $1.5868 \mathrm{E}-02$ \\
\hline 4 & Hippomane mancinella & 6 & $75 \%$ & 19 & 0.0238 & 0.0178 & 1.010 & $1.7995 \mathrm{E}-02$ \\
\hline
\end{tabular}

Absolute frequency $(\mathrm{fa})=$ presence of the species in the different quadrats; Relative frequency $($ fr $)=$ Absolute frequency / by the number of quadrats; Density = number of individuals / survey area; Index of distribution (Id) = Relative frequency * Density; Index of dominance $(I D)=$ Index of distribution * basal area

Dichrostachys cinerea is the predominant species due to its large number of individuals and its high distribution within the station. The individuals of the station present low section and height measurements except for three mature trees, Hippomane mancinella, Thespesia populnea and Tabebuia heterophylla, in relatively large numbers which present high section (between 2.5 and $45 \mathrm{~cm}$ ) and height (between 1 and $15 \mathrm{~m})$ measurements. Regenerations of other individuals present much lower measurements (sections between 2.5 and $5 \mathrm{~cm}$ ). 


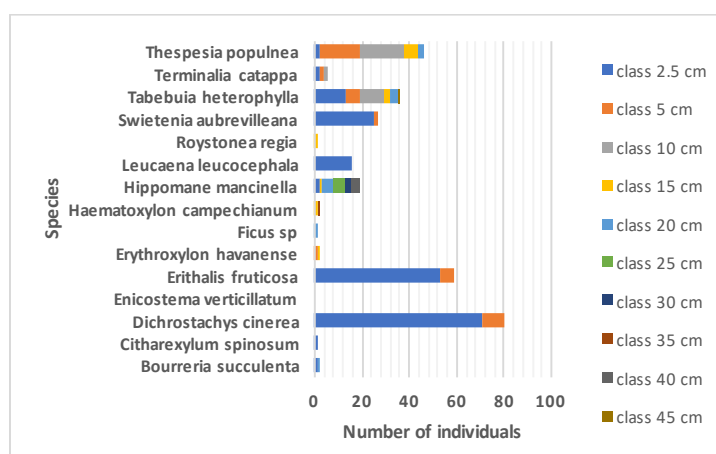

Figure 0.25 : Diametric distribution of living trees (diameters $\geq 2.5 \mathrm{~cm} ;$ Station M2)

\section{General summary}

Stations M1 and M2 represent unbalanced formations. The Index of dominance is not representative as it overwrites the species with the highest densities. For the analysis of these two stations, we did not take into account the Index of dominance; we looked at the number of individuals and the Index of distribution.

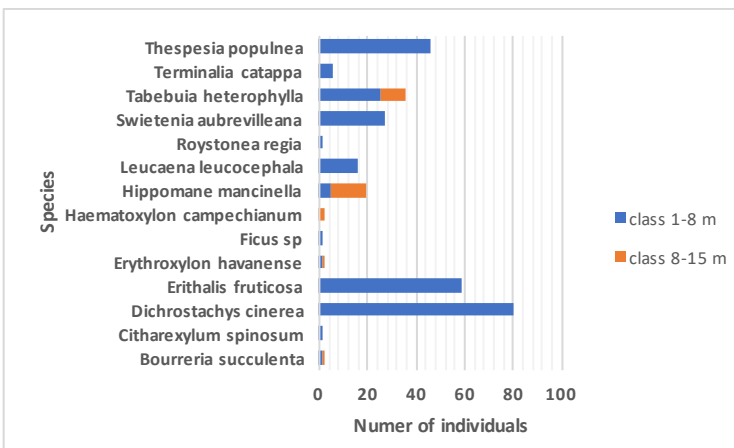

Figure 0.26: Height distribution of living trees (heights $\geq 1.3 \mathrm{~m} ;$ Station M2)

Analysing our data, we can see that Dichrostachys cinerea presents a number of individuals (excluding dead trees and regeneration) and the highest indices of distribution.

Dichrostachys cinerea is therefore the most competitive species of these two stations.

Station M3

Table 0.14 : The main ecological and structural parameters (Station M3)

\begin{tabular}{|c|c|c|c|c|c|c|c|c|}
\hline Rank & Species M3 & fa & fr & $\begin{array}{l}\text { Number of individuals per species } \\
\text { excluding regenerations and dead trees }\end{array}$ & $\begin{array}{l}\text { Density } \\
(\text { ind/m²) }\end{array}$ & Id & $\begin{array}{l}\text { Total basal area } \\
\text { per species }\end{array}$ & ID \\
\hline 1 & Bourreria succulenta & 5 & $100 \%$ & 259 & 0.518 & 0.518 & 0.1625 & $8.4164 \mathrm{E}-02$ \\
\hline 2 & Dichrostachys cinerea & 5 & $100 \%$ & 153 & 0.306 & 0.306 & 0.1694 & $5.1822 \mathrm{E}-02$ \\
\hline 3 & $\begin{array}{l}\text { Haematoxylon } \\
\text { campechianum }\end{array}$ & 5 & $100 \%$ & 63 & 0.126 & 0.126 & 0.2989 & $3.7667 \mathrm{E}-02$ \\
\hline 4 & Tabebuia heterophylla & 5 & $100 \%$ & 28 & 0.056 & 0.056 & 0.3574 & $2.0012 \mathrm{E}-02$ \\
\hline 5 & Swietenia aubrevilleana & 4 & $80 \%$ & 36 & 0.072 & 0.0576 & 0.2322 & $1.3374 \mathrm{E}-02$ \\
\hline 6 & Croton bixoides & 5 & $100 \%$ & 95 & 0.19 & 0.19 & 0.0628 & $1.1938 \mathrm{E}-02$ \\
\hline
\end{tabular}

Absolute frequency $(\mathrm{fa})=$ presence of the species in the different quadrats; Relative frequency $($ fr $)=A b s o l u t e$ frequency / by the number of quadrats; Density = number of individuals / survey area; Index of distribution (Id) = Relative frequency * Density; Index of dominance $(I D)=$ Index of distribution $*$ basal area

This seasonal tropical evergreen plant of lower horizon and xeric facies is at the bush stage. The species of the plant cortege are identical to those of the M1 station. The dominant procession, in order of ecological significance, is Bourreria succulenta, Dichrostachys cinerea and Haematoxylon campechianum.
Bourreria succulenta and Dichrostachys cinerea present a high number and density whereas the index of dominance of Haematoxylon campechianum is offset by a small number of large section individuals (Figure 4.27). 153 Dichrostachys cinerea individuals were identified. These have a relatively high diametric distribution (between 2.5 and $10 \mathrm{~cm}$ ). The plant matrix is composed mainly of individuals of small section and height measurements (Figures 4.27 and 4.28). 
Some Aspects of the Ecology of a Potentially Invasive Species in Martinique: The Case of Dichrostachys cinerea

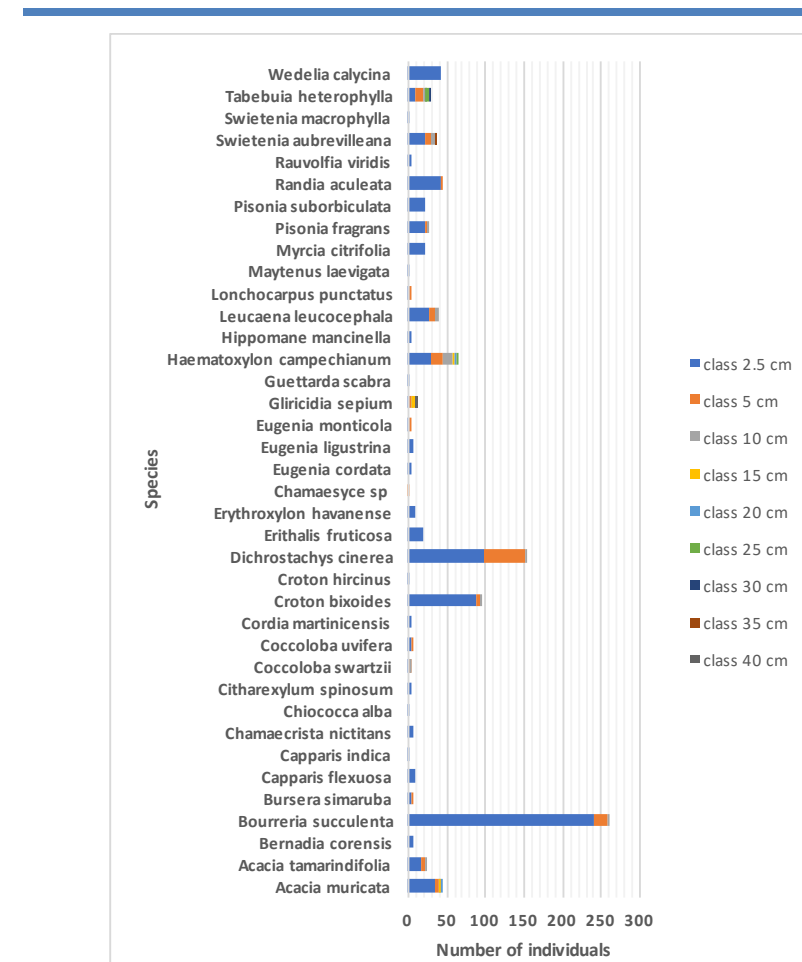

Figure 0.27 : Diametric distribution of living trees (diameters $\geq 2.5 \mathrm{~cm}$; Station M3)

\section{General summary}

The five stations (M1, M2, M3, V7 and V8) describe phytocenoses at the bush stage. The plant cortege consisted of herbaceous plants and bushes except for a few mature trees (Haematoxylon campechianum, Thespesia populnea, Tabebuia heterophylla, Swietenia aubrevilleana, Hippomane mancinella)

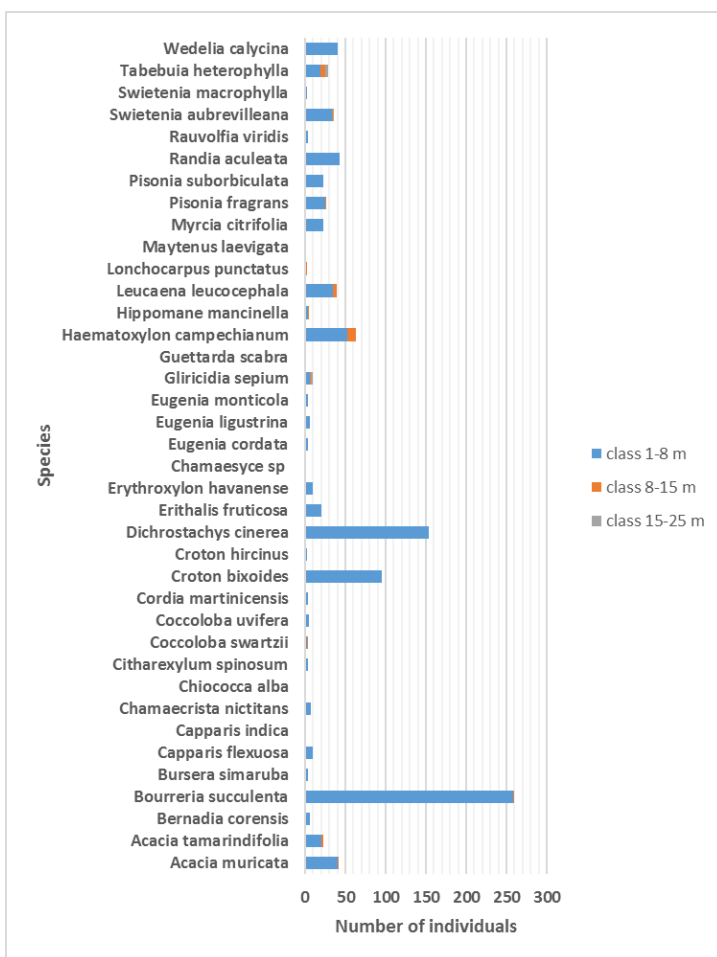

Figure 0.28: Height distribution of living trees (heights $\geq 1.3 \mathrm{~m} ;$ Station M3)

having reached their level of optimal morphogenetic development.

In these stations, the opening of the canopy has enabled the installation and development of the most competitive species, Dichrostachys cinerea. In these plant communities, the species has managed to form monospecific

thickets.

\subsection{Dominance ratio for all stations}

Table 0.15 : The main ecological and structural parameters for all stations

\begin{tabular}{|c|c|c|c|c|c|c|c|}
\hline Species & fa & fr & $\begin{array}{l}\text { Number of individuals per species excluding } \\
\text { regenerations and dead trees }\end{array}$ & $\begin{array}{l}\text { Density } \\
\text { (ind//m²) }\end{array}$ & Id & $\begin{array}{l}\text { Total basal area } \\
\text { per species }\end{array}$ & ID \\
\hline Dichrostachys cinerea & 14 & $100 \%$ & 915 & 0.1787 & 0.1787 & 0.8183 & $1.4624 \mathrm{E}-01$ \\
\hline Pisonia fragrans & 12 & $86 \%$ & 577 & 0.1127 & 0.0966 & 1.6140 & $1.5591 \mathrm{E}-01$ \\
\hline Bourreria succulenta & 11 & $79 \%$ & 553 & 0.1080 & 0.0849 & 0.8036 & 6.8193E-02 \\
\hline Croton bixoides & 11 & $79 \%$ & 520 & 0.1016 & 0.0798 & 0.4437 & $3.5411 \mathrm{E}-02$ \\
\hline Erythroxylon havanense & 12 & $86 \%$ & 449 & 0.0877 & 0.0752 & 0.5782 & $4.3466 \mathrm{E}-02$ \\
\hline Capparis indica & 12 & $86 \%$ & 322 & 0.0629 & 0.0539 & 0.2611 & $1.4077 \mathrm{E}-02$ \\
\hline Capparis flexuosa & 11 & $79 \%$ & 154 & 0.0301 & 0.0236 & 0.1050 & $2.4826 \mathrm{E}-03$ \\
\hline Acanthocereus tetragonus & 5 & $36 \%$ & 307 & 0.0600 & 0.0214 & 0.5856 & $1.2541 \mathrm{E}-02$ \\
\hline Zanthoxylum monophyllum & 8 & $57 \%$ & 177 & 0.0346 & 0.0198 & 0.8045 & $1.5893 \mathrm{E}-02$ \\
\hline $\begin{array}{l}\text { Haematoxylon } \\
\text { campechianum }\end{array}$ & 4 & $29 \%$ & 200 & 0.0391 & 0.0112 & 0.9665 & $1.0787 \mathrm{E}-02$ \\
\hline
\end{tabular}

Absolute frequency $(\mathrm{fa})=$ presence of the species in the different quadrats; Relative frequency (fr) $=$ Absolute frequency / by the number of quadrats; Density = number of individuals / survey area; Index of distribution $($ Id $)=$ Relative frequency * Density; Index of dominance $(I D)=$ Index of distribution * basal area

Table 4.16 shows the dominance of the species with regards to each other for all the stations. In a similar manner to the two previous cases (stations M1 and
M2), we looked at the number of individuals and the index of distribution. The species which are most represented in the totality of the stations are: 
Some Aspects of the Ecology of a Potentially Invasive Species in Martinique: The Case of Dichrostachys cinerea

Dichrostachys cinerea, Pisonia fragrans, Bourreria succulenta, Croton bixoides, Erythroxylon havanense and Capparis indica (Table 4.16).
Dichrostachys cinerea differs from the other species in its high number of individuals and high level of density. For all the stations, it is the most competitive species with regard to the environmental factors.

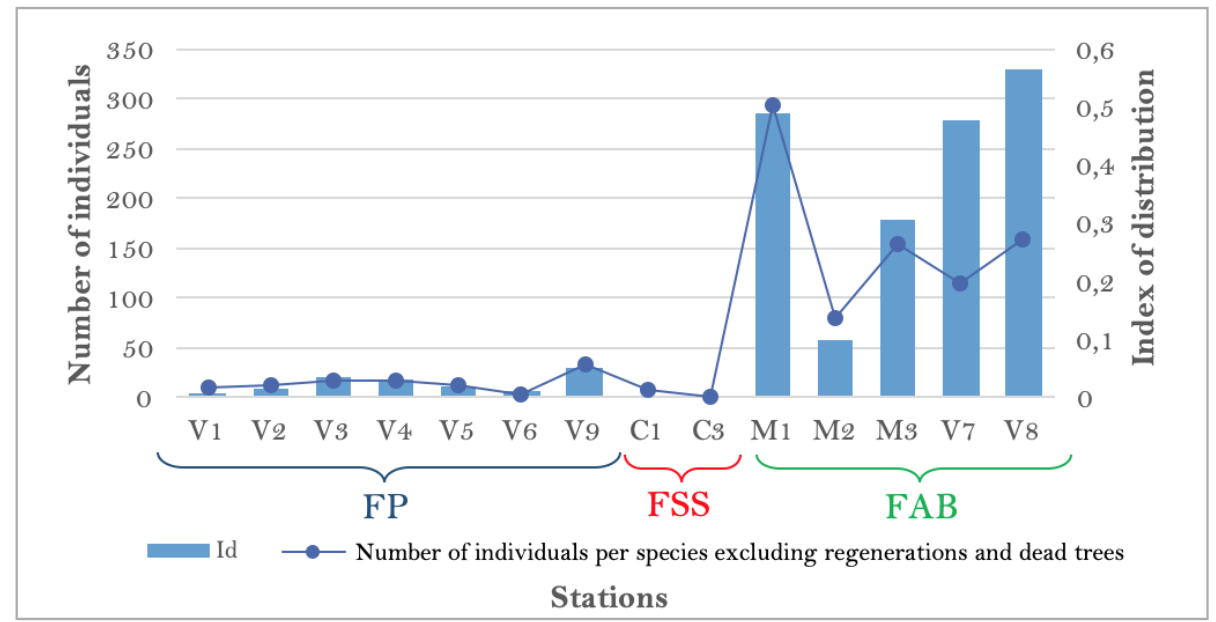

Figure 0.29 : Abundance of Dichrostachys cinerea in all stations

To complete our observation, we plotted the number of individuals excluding regenerations and dead trees in the primary axis and the index of distribution in the secondary axis according to the stations we inventoried. The data indicate variations in the abundance of Dichrostachys cinerea depending on the different stations. Dichrostachys cinerea has great capacity to install in several biocenotic conditions. It is a plastic species.

\section{Discussion}

\section{$1.7 \quad C F A$ and $A H C$}

The study areas comprise 114 plant species divided into 49 families and 97 genera.

Dichrostachys cinerea was found in all stations we inventoried. We identified 915 mature individuals (excluding seedlings and dead trees) (Table 4.16). The individuals we counted have diameters measuring between 2.5 and $15 \mathrm{~cm}$. Depending on the dynamic development stage of the stations (sylvatic secondary, presylvatic or bush), we observed variations in the dominance of the species. In some stations, the species forms monospecific stands.

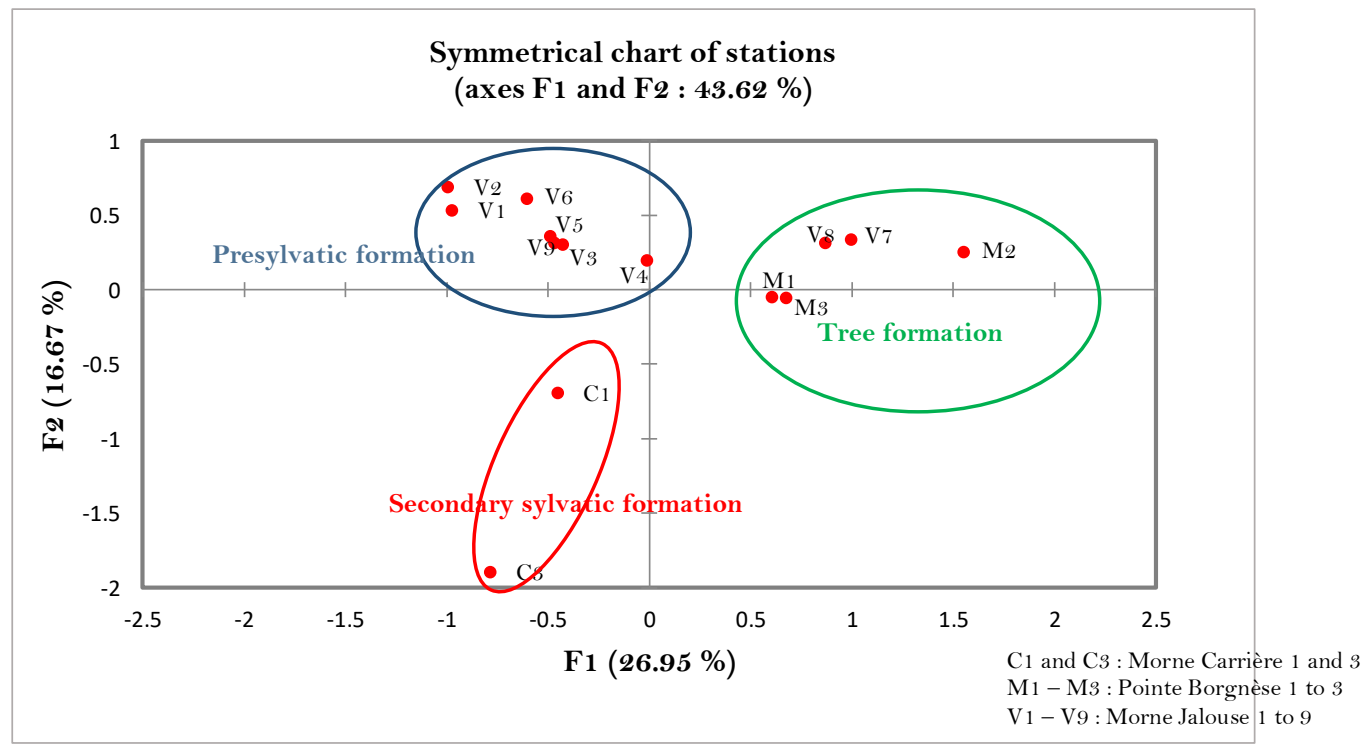

Figure 0.1 : Representation of the CFA in the factorial design 1,2 
This CFA (Confirmatory Factor Analysis) allowed us to identify the essential relationships existing between species and stations. The inertia generated by the first axis is $26.95 \%$ and that of the second axis is $16.67 \%$. These two axes express a maximum of inertia of $43.62 \%$ (Figure 5.1). The analysis was conducted in the stations with the same mesological conditions. Axis 1 distinguishes changes in the floristic composition between the different stations. Axis 2 highlights a dynamic and ecological gradient of the plant formations of each of the stations.

This CFA disclosed plant formations in three dynamic stages. Stations V1, V2, V3, V4, V5, V6 and V9 have a similar floristic composition because they present values which are highly homogeneous.
The development of woody heliophilous species (Pisonia fragrans, Zanthoxylum monophyllum) leads to a gradual closure of the stratum. They correspond to plant communities located between pre-forest to bush stages. Stations M1, M2, M3, V4, V8 and V7 represent the most degraded stations. They relate to bush strata marked mainly by individuals of low biomasses punctuated by some mature trees of significant sections. They belong to bush formations. Stations $\mathrm{C} 1$ and $\mathrm{C} 3$ have a similar floristic composition: they are made up of old pioneer ecounits (Citharexylum spinosum and Haematoxylon campechianum) and give way to post-pioneer ecounits (Bursera simaruba and Lonchocarpus punctatus). They belong to secondary sylvatic formations.

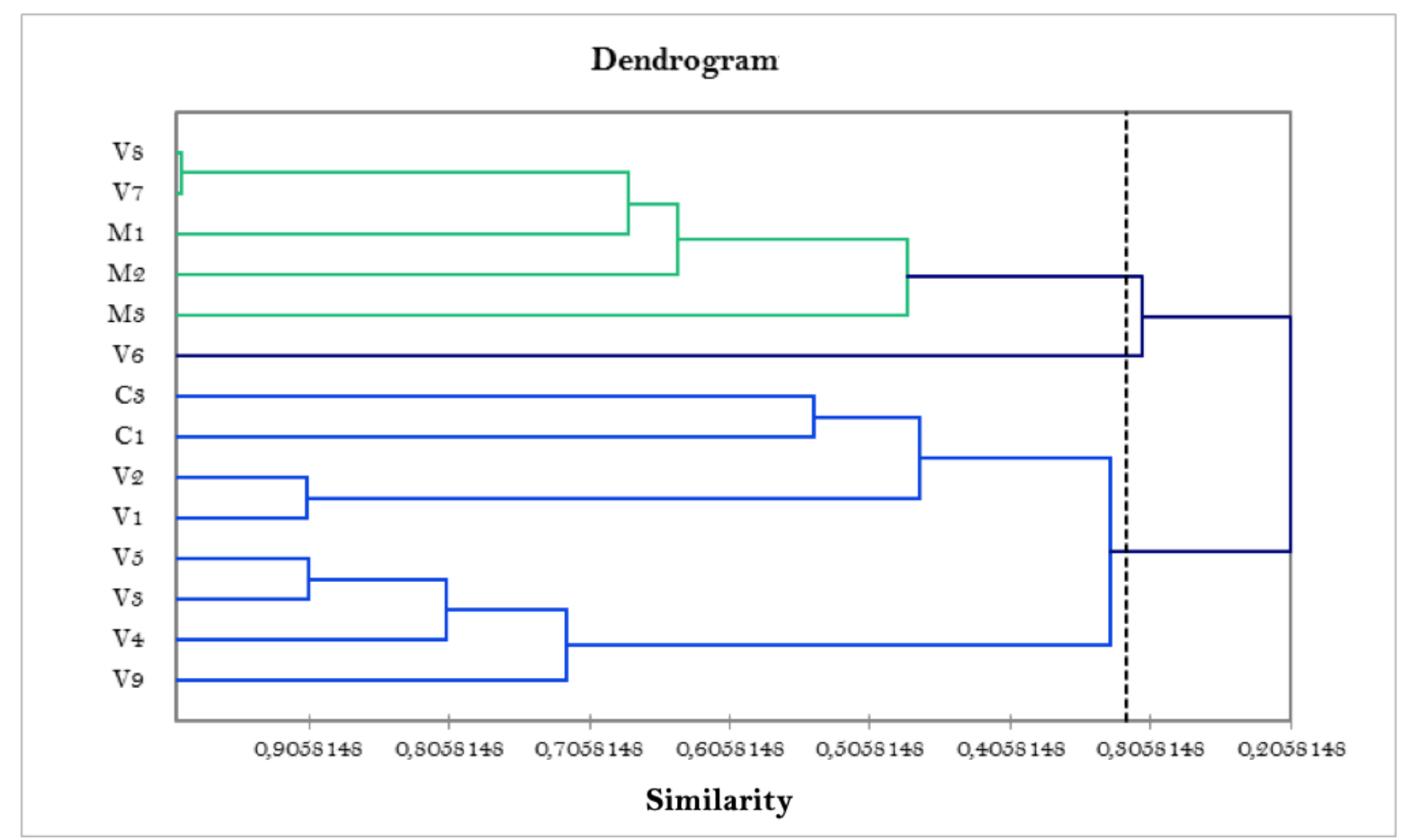

Figure 0.2 : Hierarchy of partitions obtained by AHC

The results of the AHC (Ascending Hierarchical Classification) confirm those obtained by projection of the individuals in factorial designs based on the CFA. The AHC shows a more crude analysis than with the CFA. However, this method (the AHC) shows that stations V7 and V8 have a very similar floristic composition. Indeed, in these two stations, Dichrostachys cinerea is the dominant species and the other species are very marginal. Stations V9, V4, V3 and V5 are fairly homogeneous. In a more refined/affine manner, stations V3 and V5 are the most similar.

\section{Conclusion}

Invasive plants are the direct cause of the regression, instability, or disappearance of autochthonous species or even species communities. In addition, they lead to the homogenisation of fauna and ecosystems and are also the source of emerging diseases. Martinique is a small island system characterised by highly anthropogenic vegetation.

The communes studied (Marin and Vauclin) are both areas with very high and medium ecosystem vulnerabilities. Dichrostachys cinerea is a threat to the development of autochthonous and/or indigenous species. 
In addition to the fact that it produces its own regenerations, it continues to expand progressively in the bush, presylvatic and secondary sylvatic stages.

In conclusion, Dichrostachys cinerea possesses the profile and ecological traits of a naturalised plant in the study area as it has invaded all areas unoccupied by autochthonous species. Moreover, its manner of inserting itself in different biocenotic conditions makes it possible to describe the plasticity of the species with regard to the environments.

\section{References}

1. Abati Y., Baillard K., Joseph P., Ely-Marius S., JeanFrançois Y., Ecology of potentially invasive species in Martinique: Triphasia trifolia, Journal of Advances in Biology, Volume 9, Numéro 4, 2017, p 2000 - 2016

2. Fournet J., Flore illustrée des phanérogames de Guadeloupe et de Martinique, Cirad - Gondwana, 2002

3. Howard R. A., et Col, Flora of the Lesser Antilles. Leeward and Windward Islands. Arnold Arboretum, Harvard University. Jamaica Plain, Massachusetts, 1988.

4. Jakobs G., Weber E., Edwards P.J., Introduced plants of the invasive Solidago gigantea (Asteraceae) are larger and grow denser than conspecifics in the native Rowe, Diversity and Distributions, Volume 10, Issue 1, 2004, p $11-19$

5. Joseph P., Dynamique, écophysiologie végétale en bioclimat sec à la Martinique, Thèse de doctorat, Université des Antilles et de la Guyane, Septentrion - Presses universitaires, Lille, 1997

6. Joseph P., Les monuments naturels : objets opératoires dans l'aménagement de l'écosystème- Martinique, Terre d'Amérique, Paris, GEODE Caraïbe-Karthala, Numéro 2 , 1999, p $209-226$

7. Joseph P., La question des Species invasives dans les Petites Antilles : Le cas de la Martinique. In : Expertise et spatialisation des connaissances en environnement, Presses universitaires d'Orléans, Collection CEDETE, 2004, p 328 339

8. Joseph P., Les Petites Antilles face aux risques d'invasion par les Species végétales introduites. L'exemple de la Martinique. Revue d'écologie, 61, 2006, p 209 - 224

9. Joseph P., Forêts et Species introduites. In : La végétation forestière des Petites Antilles : synthèse bibliographique et écologique, bilan et perspectives, Paris : Karthala, 2009, p $341-373$

10. Joseph P., La végétation des Petites Antilles : principaux traits floristiques et effets plausibles du changement climatique. VertigO - la revue électronique en sciences de l'environnement, Volume 11, Numéro 1, mai 2011. Disponible sur : <https://vertigo.revues.org/10886> (consulté le 02/02/2016)

11. Joseph P., Quelques traits généraux de la diversité sylvatique des Petites Antilles. VertigO - la revue électronique en sciences de l'environnement, Hors - série 14, septembre 2012. Disponible sur : <https://vertigo.revues.org/12492\#toctoln1> (consulté le 02/02/2016)

12. Joseph P., Baillard K., Ely-Marius S., Abati Y., Claude J.P., Jean-François Y., Etude floristique et écologique en vue de la mise en place d'une exploitation de substratums géologiques (Morne Carrière - Commune du Vauclin) Expertise environnementale systémique, Rapport scientifiques, 2015, $87 \mathrm{p}$
13. Joseph P., Baillard K., Ely-Marius S., Abati Y., Claude J. P., Jean-Francois Y., Etude floristique et écologique ZNIEFF Fond Rousseau / Morne la Pirogue / Terreville, Rapport scientifiques, 2015, $63 \mathrm{p}$

14. Joseph P., Simphor J.-E., Baillard K., Claude J.-P., Abati Y. Jean-François Y., Ely-Marius S., Contribution to the knowledge of the Lesser Antilles flora : Study of the Case Navire, naturalistic area of ecological fauna and flora interest (Martinique), International Journal of Advanced Research, Volume 4, Numéro 8, 2016, p 1210 - 1239

15. Joseph P., Abati Y., The flower plants introduced in the Lesser Antilles: Martinique's example (general summary of the key data and ecosystem impacts), Journal of Environmental Science, Toxicology and Food Technology, Volume 10, Issue 8, 2016, $21 \mathrm{p}$

16. Joseph P., Simphor J.-E., Bailard K., Ely-Marius S., Claude J.-P., Abati Y., Jean-François Y., The Effects of Topography on Martinique's Mesological and Floristic Differentiations: the Case of Morne Carrière (Commune of Vauclin), Journal of Environmental Science, Toxicology and Food Technology, Volume 11, Issue 1, Ver.III, 2017, p $74-96$

17. Joseph P., Baillard K., Abati Y., Ely- Marius S., Claude J.P., Sophie S., Belfan D., Lieu-dit "Trou Manuel" Commune du Marin (Martinique) Caractérisation écologique des principaux éléments de la flore et de la faune, Rapport scientifique, 2018, $84 \mathrm{p}$

18. Legros J.-P., Vertisols. In : Les grands sols du monde, $1^{\text {ère }}$ éd. PUR, 2007, p 223 - 249

19. Météo - France Antilles Guyane, Projection Climatique régionalisée en Martinique. Rapport disponible à la demande. Données climatiques de la station du Vauclin

20. Météo - France Antilles Guyane, Projection Climatique régionalisée en Martinique. Rapport disponible à la demande. Données climatiques de la station du Marin

21. Podwojewski P., Les vertisols de Nouvelle - Calédonie, Rapports Scientifiques et Techniques Sciences de la Terre, Biological Sciences, Volume 78, p 288 - 298

22. Raizada P., Raghubanshi A.S., Singh J.S., Impact of alien plant species on soil processes : a review, Biological Sciences, Volume 78, 2008, p $288-298$

23. Richards C. L., Bossdorf O., Muth N.Z., Gurevitch G., Pigliucci M., Jack of all trades, master of some? On the role of phenotypic plasticity in plant invasions, Ecology Letters, 2006, Volume 9, Numéro 8, p 981 - 993

24. Richardson D.M, Pysek P., Rejmànek M., Barbour M.G., Panetta F.D., West C.J., Naturalization and invasion of alien plants : concepts and definitions, Diversity and Distributions, Volume 6, 2000, p $713-724$

25. Rouget M. Richardson D.M., Nel J.L., Van Wilgen B.W., Commercially important trees as invasive aliens - towards spatialy explicit risk assessment at a national scale, Biological Invasions, Volume 4, 2002, p $215-236$

26. Terral J.- F., Ater M., Implications écologiques de l'étude de la plasticité de caractères anatomiques du bois d'olivier (Olea europaea L.). In : Ater M. (ed.), Essalouh L. (ed.), Ilbert H.(ed.), Moukhli A. (ed.), Khadari B. (ed.). L'oléiculture au Maroc de la préhistoire à nos jours : pratiques, diversité, adaptation, usages, commerce et politiques. Montpellier : CIHEAM, 2016, p. 171-179 (Options Méditerranéennes : Série A. Séminaires Méditerranéens ; n. 118)

27. Williamson M.H., Brown K.C., The analysis and modelling of British invasions, Biological Sciences, Volume 314, Issue 1167,1986, p $505-522$

28. Williamson M., Fitter A., The varying success of invaders, Ecology, Volume 78, Numéro 6, 1996, p 1661 - 1666 